\title{
Mast Cell Coupling to the Kallikrein-Kinin System Fuels Intracardiac Parasitism and Worsens Heart Pathology in Experimental Chagas Disease
}

OPEN ACCESS

Edited by:

Kenneth J. Gollob,

Mario Penna Institute, Brazil

Reviewed by: Alvin H. Schmaier,

Case Western Reserve University,

United States

Marcus Maurer,

Charité Universitätsmedizin Berlin,

Germany

*Correspondence:

Julio Scharfstein

jscharf2@gmail.com

these authors have contributed equally to this work.

Specialty section:

This article was submitted to Microbial Immunology, a section of the journal

Frontiers in Immunology

Received: 05 June 2017

Accepted: 04 July 2017

Published: 02 August 2017

Citation:

Nascimento CR, Andrade D,

Carvalho-Pinto $C E$, Serra RR,

Vellasco L, Brasil G, Ramos-Junior ES,

da Mota JB, Almeida LN,

Andrade MV, Correia Soeiro MdN,

Juliano L, Alvarenga PH, Oliveira AC,

Sicuro FL, de Carvalho ACC,

Svensjö E and Scharfstein J (2017)

Mast Cell Coupling to the

Kallikrein-Kinin System Fuels

Intracardiac Parasitism and Worsens

Heart Pathology in Experimental

Chagas Disease.

Front. Immunol. 8:840.

doi: 10.3389/fimmu.2017.00840
Clarissa R. Nascimento ${ }^{1 \dagger}$, Daniele Andrade ${ }^{1 \dagger}$, Carla Eponina Carvalho-Pinto ${ }^{2}$, Rafaela Rangel Serra', Lucas Vellasco', Guilherme Brasil', Erivan Schnaider Ramos-Junior ${ }^{1,3}$, Julia Barbalho da Mota ${ }^{1}$, Larissa Nogueira Almeida', Marcus V. Andrade ${ }^{4,5}$, Maria de Nazaré Correia Soeiro ${ }^{6}$, Luiz Juliano ${ }^{7}$, Patrícia Hessab Alvarenga ${ }^{8}$, Ana Carolina Oliveira', Fernando Lencastre Sicuro', Antônio C. Campos de Carvalho', Erik Svensjö ${ }^{1}$ and Julio Scharfstein ${ }^{1 *}$

'Instituto de Biofísica Carlos Chagas Filho, Universidade Federal do Rio de Janeiro (UFRJ), Rio de Janeiro, Brazil, ${ }^{2}$ Departamento de Imunobiologia, Universidade Federal Fluminense (UFF), Niterói, Brazil, ${ }^{3}$ University of the Pacific, San Francisco, CA, United States, ${ }^{4}$ Faculdade de Medicina, Universidade Federal de Minas Gerais (UFMG), Belo Horizonte, Brazil, ${ }^{5}$ Departamento de Clinica Medica, Universidade Federal de Minas Gerais (UFMG), Belo Horizonte, Brazil, ${ }^{6}$ Instituto Oswaldo Cruz, Fundação Oswaldo Cruz (Fiocruz), Rio de Janeiro, Brazil, ${ }^{7}$ Universidade Federal de São Paulo (UNIFESP), São Paulo, Brazil, ${ }^{8}$ Instituto de Bioquímica Médica Leopoldo de Meis (IBqM), Universidade Federal do Rio de Janeiro, Rio de Janeiro, Brazil, ${ }^{\circ}$ Universidade do Estado do Rio de Janeiro (UERJ), Centro Biomédico Rio de Janeiro, Rio de Janeiro, Brazil

During the course of Chagas disease, infectious forms of Trypanosoma cruzi are occasionally liberated from parasitized heart cells. Studies performed with tissue culture trypomastigotes (TCTs, Dm28c strain) demonstrated that these parasites evoke neutrophil/CXCR2-dependent microvascular leakage by activating innate sentinel cells via toll-like receptor 2 (TLR2). Upon plasma extravasation, proteolytically derived kinins and C5a stimulate immunoprotective Th1 responses via cross-talk between bradykinin B2 receptors (B2Rs) and C5aR. Awareness that TCTs invade cardiovascular cells in vitro via interdependent activation of B2R and endothelin receptors [endothelin A receptor $\left(E T_{A} R\right) / e n d o t h e l i n$ B receptor $\left(E T_{B} R\right)$ ] led us to hypothesize that $T$. cruzi might reciprocally benefit from the formation of infection-associated edema via activation of kallikreinkinin system (KKS). Using intravital microscopy, here we first examined the functional interplay between mast cells (MCs) and the KKS by topically exposing the hamster cheek pouch (HCP) tissues to dextran sulfate (DXS), a potent "contact" activator of the KKS. Surprisingly, although DXS was inert for at least $30 \mathrm{~min}$, a subtle MC-driven leakage resulted in factor XII (FXII)-dependent activation of the KKS, which then amplified inflammation via generation of bradykinin (BK). Guided by this mechanistic insight, we next exposed TCTs to "leaky" HCP_forged by low dose histamine application-and found that the proinflammatory phenotype of TCTs was boosted by BK generated via the $\mathrm{MC} / \mathrm{KKS}$ pathway. Measurements of footpad edema in MC-deficient mice linked TCT-evoked inflammation to MC degranulation (upstream) and FXII-mediated generation of BK (downstream). We then inoculated TCTs intracardiacally in mice and found a 
striking decrease of parasite DNA (quantitative polymerase chain reaction; 3 d.p.i.) in the heart of MC-deficient mutant mice. Moreover, the intracardiac parasite load was significantly reduced in WT mice pretreated with (i) cromoglycate (MC stabilizer) (ii) infestin-4, a specific inhibitor of FXIla (iii) HOE-140 (specific antagonist of B2R), and (iv) bosentan, a non-selective antagonist of $E T_{A} R / E T_{B} R$. Notably, histopathology of heart tissues from mice pretreated with these $G$ protein-coupled receptors blockers revealed that myocarditis and heart fibrosis (30 d.p.i.) was markedly and redundantly attenuated. Collectively, our study suggests that inflammatory edema propagated via activation of the MC/KKS pathway fuels intracardiac parasitism by generating infection-stimulatory peptides (BK and endothelins) in the edematous heart tissues.

Keywords: bradykinin, Chagas disease, endothelin, G protein-coupled receptors, kallikrein, mast cells, Trypanosoma cruzi

\section{INTRODUCTION}

Although the complement system is a classic example of a proteolytic cascade that stimulates immunity through the generation of proinflammatory peptides, studies in different infectious disease models extended this concept to the kallikrein-kinin system (KKS) (1). Intravascular activation of the KKS is initiated when the zymogen factor XII (FXII) interacts with a broad range of endogenous "contact" substances (2), including negatively charged polymers, such as platelet-derived polyphosphates (polyP) (3) and DNA associated with neutrophil extracellular traps (4). Trace formation of FXIIa in the blood is sufficient to convert the prekallikrein into active plasma kallikrein (PKa), a serine protease that reciprocally cleaves FXII. Feedback cycles of activation between PK/FXII lead to FXIIa-mediated cleavage of FXIa. Further downstream, FXIa generates FIXa-the effector of fibrin formation via the intrinsic pathway of coagulation. In parallel, PK activates the proinflammatory KKS by proteolytically excising bradykinin (BK) from an internal moiety of high molecular weight kininogen (HK). Acting as a paracrine mediator, the short-lived BK induces vasodilation and increases microvascular permeability via activation of endothelial bradykinin $\mathrm{B} 2$ receptor (B2R), a constitutively expressed subtype of kinin receptor (5). In addition, $\mathrm{PK}$ promotes plasmin-dependent fibrinolysis and C3 activation, hence couples FXIIa-dependent thrombogenesis to fibrinolytic and immunological mechanisms. As inflammation persists, a GPI-linked carboxypeptidase M removes the C-terminal arginine from the primary kinin, thus converting the B2R agonist into a high-affinity ligand for bradykinin $\mathrm{B} 1$ receptor (B1R) (6), a G protein-coupled receptor (GPCR) subtype that is transcriptionally upregulated in injured tissues by proinflammatory cues, such as IL- $1 \beta$, TNF- $\alpha(7,8)$, or by prooxidative polypeptides, e.g., angiotensin II and endothelin-1 (ET-1) (9).

Abbreviations: BK, bradykinin; B1R, bradykinin B1 receptor; B2R, bradykinin B2 receptor; HK, high molecular weight kininogen; LK, low molecular weight kininogen; LBK, lysyl-BK; GPCR, G protein-coupled receptor; ACE, angiotensinconverting enzyme; PKa, plasma kallikrein; KKS, kallikrein-kinin system; FXII, coagulation factor XII; MCs, mast cells; CCC, chronic chagasic cardiomyopathy; $\mathrm{HCP}$, hamster cheek pouch; ET-1, endothelin-1; $\mathrm{ET}_{\mathrm{A}} \mathrm{R}$, endothelin A receptor; $\mathrm{ET}_{\mathrm{B}} \mathrm{R}$, endothelin $\mathrm{B}$ receptor; DXS, dextran sulfate; TCTs, tissue culture trypomastigotes; $\mathrm{H} 1 \mathrm{R}$, histamine $\mathrm{H} 1$ receptor; polyP, polyphosphates.
During infection or sterile inflammation, subtle increases in endothelial permeability allow for the extravascular accumulation/diffusion of plasma proteins, including complement components and blood-borne kininogens (high or low molecular weight) (1). Using animal models of severe MC-mediated allergic reactions, Sala-Cunill et al. (10) showed that BK fueled inflammation via mechanisms involving activation of FXII by endogenous contact factors released from MC granules, e.g., heparin (11) and/or PolyP (12). Once liberated by PK, the short-lived BK rapidly potentiates allergic inflammation via iterative cycles of B2R-dependent activation of the endothelium and plasma leakage. During infection, kinins can be released extravascularly by the action of microbial kininogenases, such as cruzipain and gingipains, i.e., cysteine proteases respectively expressed by the parasitic protozoan Trypanosoma cruzi (13) and the periodontal bacteria Porphyromonas gingivalis $(14,15)$, both of which object of systematic investigations in vitro and in vivo.

Afflicting approximately 8 million people in Latin America (16), Chagas disease, the heart pathology caused by chronic T. cruzi infection, remains incurable (17). Human infection starts when the blood seeking triatomine releases infective forms (metacyclic trypomastigotes) on tissues lacerated by the proboscis. Alternatively, T. cruzi is transmitted orally following ingestion of macerated fruit juices that were contaminated with infected bugs $(18,19)$. The life cycle of T. cruzi in mammals requires an obligate stage of intracellular development in a broad range of host cells, including epithelial cells, tissue-resident macrophages, and cardiomyocytes. After invading host cells via a mechanism akin to endocytosis, the trypomastigotes rapidly escape from parasitophorous vacuole and reach the host cell cytoplasm, where they transform into oval-shaped amastigotes (replicating forms). After coopting the host cell metabolism to support amastigote division for several days (20), the amastigotes transform into infective trypomastigotes. Upon cell death, the extracellular trypomastigotes navigate away from the primary foci of infection and enter the bloodstream from where the infection is disseminated. Characterized by high blood parasitemia and systemic inflammation, acute Chagas disease subsides with the onset of adaptive immunity. However, a low-grade infection (asymptomatic) persists for several years before development of clinical symptoms. Although a minority of patients present 
digestive system complications (megacolon), about $25 \%$ of the chronically infected chagasic patients develop a progressive and as yet incurable cardiomyopathy [chronic chagasic cardiomyopathy (CCC)] (21).

Clinical and histopathological studies in T. cruzi-infected mice have linked severity of CCC to immunoregulatory abnormalities (22). Systematic investigations in mice models of chronic Chagas disease indicated that chronic myocarditis/fibrosis worsens as a consequence of an imbalance between protective versus pathogenic subsets of heart-infiltrating IFN- $\gamma$ and perforin-producing $\mathrm{CD}^{+} \mathrm{T}$ cells (23). More recently, cohort studies performed in Spain revealed that chronic chagasic patients display a hypercoagulopathy phenotype (24). Although the role of the contact system was not explored in this particular study, these findings raise the possibility that, over the years, activated monocytes circulating in the bloodstream of chronic chagasic patients might forge the coupling between the extrinsic/intrinsic pathways of coagulation (1). While not excluding a primary role for infectionassociated immunopathology (25), it was reported that patients with chronic myocardiopathy display marked abnormalities in heart microvessels and extracellular matrix. Insight on the molecular basis of CCC emerged from experimental studies (26) showing that parasitized cardiomyocytes upregulate the expression of ET-1, a potent vasoconstrictor and profibrosing polypeptide. Extending this analysis to in vivo setting, these authors showed evidence that heart fibrosis was attenuated in transgenic mice in which ET-1 was genetically ablated from cardiomyocytes-but not from endothelial cells. While these studies were in progress, our group suggested that generation of kinins may have a dual role in host/parasite equilibrium (27). Acting on the behalf of host defenses, the released kinins stimulate B2R expressed by immature dendritic cells (28), hence convert these antigen-presenting cells into inducers of IFN- $\gamma$ producing (immunoprotective) effector CD4 and CD8 T cells (29-31). Although limited to in vitro studies, the hypothesis that T. cruzi might reciprocally benefit from the activation of the KKS (27) was initially supported by evidence that tissue culture trypomastigotes (TCTs) (Dm28c strain) invade non-professional phagocytic cells (e.g., smooth muscle cells and cardiomyocytes) via cross-talk between $\mathrm{B} 2 \mathrm{R}, \mathrm{B} 1 \mathrm{R}$ and endothelin receptors [endothelin A receptor $\left(\mathrm{ET}_{\mathrm{A}} \mathrm{R}\right) /$ endothelin $\mathrm{B}$ receptor $\left(\mathrm{ET}_{\mathrm{B}} \mathrm{R}\right)$ ] $(13,27,32,33)$. Using multiple infection models, here we demonstrate that inflammatory edema propagated via the $\mathrm{MC} /$ KKS pathway fuels heart parasitism and worsens myocarditis/ fibrosis by generating infection-promoting peptides, such as kinins and endothelins. Our study illustrates how endothelial barrier destabilization, a common manifestation of inflammation, might provide T. cruzi with an opportunity to rapidly invade surrounding host cells, hence ultimately escaping from humoral immunity.

\section{MATERIALS AND METHODS}

\section{Ethics Statement}

All animal care and experimental procedures were performed in accordance to the Brazilian guidelines (Brazilian Directive for Care and Use of animals for Teaching and ResearchDBCA) published by the Brazilian Council for Control of Animal Experimentation (Conselho Nacional de Controle de Experimentação Animal-CONCEA, http://www.mct.gov.br/ upd_blob/0234/234054.pdf) and Federal Law 11.794 (October $8,2008)$. Studies involving animals are reported in compliance with the ARRIVE guidelines $(34,35)$. The protocols used in this study were approved by the Institutional Ethical Committee of Federal University of Rio de Janeiro (code number: IBCCF 101, and license protocol number 014).

\section{Mice Inbred Strains}

Colonies of $\mathrm{C} 57 \mathrm{BL} / 6$ and $\mathrm{BALB} / \mathrm{c}$ were purchased from our facilities (UFRJ, Rio de Janeiro). B6-Kit ${ }^{+/+}$(wild type) and B6-KitW-sh/W-sh (MC-deficient) were provided by one of the co-authors (M.A.; UFMG, Belo Horizonte). The experiments were conducted with male or female mice, 8- to 12-weeks-old, weighting $20-25 \mathrm{~g}$ and housed in ventilated cages under specific pathogen-free conditions, in our animal facilities at $22 \pm 2{ }^{\circ} \mathrm{C}$ with a $12 \mathrm{~h}$ light dark cycle, with access to food (normal diet) and water ad libitum. Mice were randomly allocated to each experimental group.

\section{Antibodies and Reagents}

FITC-dextran $150 \mathrm{kDa}$ and dextran sulfate (DXS) $500 \mathrm{kDa}$ were purchased from TdB Consultancy (Uppsala, Sweden). Heparin $4 \mathrm{kDa}$ (enoxaparin EUROFARMA Versa, NC 154693) was kindly provided by PAS Mourão (Universidade Federal do Rio de Janeiro). HOE-140, B2R antagonist (B2RA) was purchased from Sigma (St. Louis, MO, USA). Bosentan was a donation from Actelion (Basel, Switzerland). FXII inhibitor (36) was a generous gift from Dr. Thomas Renné (Karolinska Institute). Cromoglycate, mepyramine, histamine, captopril were purchase from Sigma (St. Louis, MO, USA). PKSI-527 and PdSP15a were supplied by the co-authors (LJ) and (PA), respectively.

\section{Generation of TCTs}

Tissue culture trypomastigotes (Dm28c, originally a gift from Dr. Samuel Goldenberg, Instituto Carlos Chagas, Fiocruz, Parana) were harvested from the supernatants of cultures of monkey kidney fibroblast cell line LLC-MK2 (American Type Culture Collection-CCL-7) 5 days after infection. The cultures were maintained in Dulbecco's Modified Eagle Medium (DMEM), 2\% heat inactivated fetal calf serum (FCS). The freshly released TCTs were washed twice with excess Hank's Balanced Saline Solution (HBSS) before being tested in vitro or in vivo, as described below.

\section{Cell Culture}

Mouse heart cells were isolated in the laboratory of one of the co-authors (MS) as previously described (37) and seeded on coverslips laid in 24-well plates. Primary cultures of mice embryonic heart cells were maintained at $37^{\circ} \mathrm{C}$ in $5 \% \mathrm{CO}_{2}$ atmosphere in DMEM, 10\% FCS to get synchronized contractility.

\section{Invasion Assays}

Tissue culture trypomastigotes were added to monolayers of primary heart cells (parasite ratio of 1:1) in DMEM containing 
$1 \mathrm{mg} / \mathrm{ml}$ human serum albumin (HAS-Baxter Pharmaceutical, Deerfield, IL, USA). Where indicated, the DMEM-HSA medium was supplemented with the angiotensin-converting enzyme (ACE) inhibitor lisinopril $(25 \mu \mathrm{M})$ and/or the following compounds (isolated or combined): HOE-140 (B2RA) $(0.1 \mu \mathrm{M})$, or cromoglycate $(140 \mu \mathrm{g} / \mathrm{ml})$. Stock solutions of HOE-140 were prepared in apyrogenic water and cromoglycate in PBS. Optimal concentration of HOE-140 was defined based on dose-response curves reported elsewhere (33). Host/parasite interactions proceeded for $3 \mathrm{~h}$ at $37^{\circ} \mathrm{C}$ in a humidified incubator, in a $5 \% \mathrm{CO}_{2}$ atmosphere. At the end point of the assay, the infected monolayers were washed three times with HBSS, fixed in Bouin and staining with Giemsa. The infection was determined by counting the number of intracellular parasites in a total of 100 cells per coverslip. Assays were performed in triplicates.

\section{Paw Edema Measurements}

B6-Kit ${ }^{+/+}, \mathrm{B} 6-\mathrm{kitW}$-sh/W-sh, and BALB/c mice, under ketamine and xilazyne anesthesia ( 80 and $8 \mathrm{mg} / \mathrm{kg}$, respectively), were injected into the hind footpad with Dm $28 \mathrm{c}$ TCTs $\left(10^{6}\right.$ parasites in $10 \mu \mathrm{l}$ of PBS) or with PBS (contralateral paw as a control). The sequential measurement of test and contralateral paws allows each mouse to serve as its own control, thus reducing animal use. Altogether, 165 mice were used. These assays were performed as previously described $(29,31,38)$. Where indicated, animals were pretreated $(-1 \mathrm{~h})$ with a single-dose of ACE inhibitor captopril ( $4 \mathrm{mg} / \mathrm{kg}$, i.p.) to minimize the degradation of kinins; HOE-140 (100 $\mu \mathrm{g} / \mathrm{kg}$ - s.c.); cromoglycate (20 mg/ $\mathrm{kg}$-i.v.); histamine $\mathrm{H} 1$ receptor (H1R) antagonist mepyramine (10 mg/kg-i.p.), or infestin-4 (FXII inhibitor; $4.5 \mathrm{mg} / \mathrm{kg}$-i.v.). Paw volume ( 3 h p.i. or $24 \mathrm{~h}$ p.i.) was measured with the aid of a plethysmometer. In the interval between measurements of 3 and $24 \mathrm{~h}$, animals were housed following the conditions described above (Mice inbred strains). At the end of the experiments, mice were euthanized by $\mathrm{CO}_{2}$ inhalation. The data obtained were expressed as difference in volume (microliters) between the test and control paws.

\section{Microvascular Permeability Measurements-Intravital Digital Microscopy}

Hamsters were purchased from Anilab (São Paulo, Brazil) and maintained in our animal facilities. The experiments were conducted with male hamsters, 3 months old, weighting 110-120 g. Altogether, 134 hamsters were used and the procedures were approved by the local ethical committee (IBCCF, license protocol number 014). Animals were anesthetized by injection of sodium pentobarbital (i.p.) supplemented with $\alpha$-chloralose $(2.5 \% \mathrm{~W} / \mathrm{V}$, solution in saline, i.v.) through a femoral vein catheter as previously described $(39,40)$. During the experimental procedures anesthesia was monitored by reflex measurement and supplemented with $\alpha$-chloralose $(2.5 \% \mathrm{~W} / \mathrm{V}$, solution in saline, i.v.) through a femoral vein catheter whenever required. A tracheal cannula (PE 190) was inserted to facilitate spontaneous breathing and the body temperature was maintained at $37^{\circ} \mathrm{C}$ by a heating pad monitored with a rectal thermistor. The hamster cheek pouch (HCP) was prepared for intravital microscopy (IVM) as reported $(14,39)$. The microcirculation of the HCP was observed after intravenous injection of the tracer FITC-dextran $150 \mathrm{kDa}(100 \mathrm{mg} / \mathrm{kg})$ using an Axioskop 40 microscope, objective $4 \times$ and oculars 10× (Carl Zeiss, Germany), equipped with appropriate filter (490/520 nm) for observations of fluorescence in epiluminescence (Colibri 2, Carl Zeiss, Germany). HCPs were continuously superfused with a HEPES-bicarbonate-buffered saline solution ( $\mathrm{pH} 7.4$; composition in mM: $110.0 \mathrm{NaCl}, 4.7 \mathrm{KCl}, 2.0 \mathrm{CaCl}_{2}, 1.2 \mathrm{MgSO}_{4}, 18.0$ $\mathrm{NaHCO}_{3}, 15.39$ HEPES, and 14.61 Na HEPES) at a constant rate of $5 \mathrm{ml} / \mathrm{min}$. A digital camera, AxioCamHRc, and a computer with the AxioVision 4.4 software program (Carl Zeiss) were used for image analysis of arteriolar diameter and total fluorescence in a representative rectangular area $\left(5 \mathrm{~mm}^{2}\right)$ of the HCP. The recorded fluorescence at $30 \mathrm{~min}$ after FITC-dextran injection [relative fluorescence units (RFUs)] in each experiment was adjusted to 2,000 RFU for statistical reasons. After an initial $30 \mathrm{~min}$ control period of continuous superfusion to verify normal microvascular flow in all vessels and absence of plasma leakage, HCPs were subjected to topical applications of different combinations of treatments, either added to superfusion solution or during interrupted superfusion in $500 \mu \mathrm{l}$ of saline on top of the HCP-tissue. After the periods of interrupted superfusion, the flow was restarted. In a first group of experiments, HCPs were exposed to DXS $500 \mathrm{kDa}(\mathrm{DXS}-0.4,2$, or $4 \mu \mathrm{M})$ followed, or not, by application of histamine $(4 \mu \mathrm{M})$, or by application of heparinized (heparin $4 \mathrm{kDa}$ ) hamster plasma $(50 \mu \mathrm{l})$. In the second protocol, the HCP (steady state) was superfused for $10 \mathrm{~min}$ with captopril $(10 \mu \mathrm{M})$ solution prior to the topical application of TCTs $\left(3 \times 10^{7}\right)$ in the presence or absence of histamine $(4 \mu \mathrm{M})$. At $60 \mathrm{~min}$ after topical application of TCTs, the HCPs were stimulated with histamine for $5 \mathrm{~min}$ as an internal control of normal reactivity of the microvasculature. Pharmacological interventions were carried out with cromoglycate (MC stabilizer, $40 \mathrm{mg} / \mathrm{kg}$, i.p.), captopril (ACE inhibitor, $10 \mu \mathrm{M}$ ), HOE-140 (B2RA; $0.5 \mu \mathrm{M}$ ), PKSI-527 (PKa inhibitor, $20 \mu \mathrm{M})(41)$, and PdSP15a (contact phase inhibitor, $20 \mu \mathrm{M})(42)$. Dose-response experiments involved superfusion of HCPs for $10 \mathrm{~min}$ with captopril $(10 \mu \mathrm{M})$ solution prior to the topical application of $60,600,6,000$, and $60,000 \mathrm{TCTs} / \mu \mathrm{l}$ in $500 \mu \mathrm{l}$ together with histamine $4 \mu \mathrm{M}$ that were followed by histamine alone $(4 \mu \mathrm{M})$ for $5 \mathrm{~min}$ at $60 \mathrm{~min}$ after TCT-application. At the end of each experiment, animals were euthanized by an overdose of pentobarbital and an i.v. injection of $\mathrm{KCl} 3 \mathrm{M}$.

\section{Contact System Activation}

The activation of FXII/PK in citrated hamster plasma-treated (or not) with DXS $500 \mathrm{kDa}$ was monitored by spectrofluorimetry as previously described $(42,43)$ using internally quenched fluorescent substrates whose sequences correspond to the C-terminal (Abz-GFSPFRAPRVQ-EDDnp) flanking region of BK of rat kininogen. The reaction was carried out in PBS, $\mathrm{pH} 7.4$, using citrated hamster plasma $(5 \%, \mathrm{v} / \mathrm{v})$ or heparin $(4 \mathrm{kDa}), 4 \mu \mathrm{M}$ of the $\mathrm{Abz}$ peptidyl-EDDnp substrate, and 4 or $20 \mathrm{nM}$ of the contact system activator DXS $(500 \mathrm{kDa})$, at $37^{\circ} \mathrm{C}$. The synthetic PKa inhibitor $(\mathrm{PKSI}-527,10 \mu \mathrm{M})(41)$ was preincubated with hamster plasma for $5 \mathrm{~min}$, at $37^{\circ} \mathrm{C}$, prior to the addition of DXS and the substrate. The hydrolysis of the cleaved substrate Abz-peptidyl-EDDnp 
$(\mathrm{Abz}=\mathrm{O}$-aminobenzoyl and $\mathrm{EDDnP}=$ ethylenediamine 2,4-dinitrophenyl) was monitored by measuring the fluorescence at $\lambda$ ex $=320 \mathrm{~nm}$ and $\lambda \mathrm{em}=420 \mathrm{~nm}$ in a fluorescence spectrophotometer (Spectramax M5-Molecular Device). Citrated or heparinized plasma (platelet free) was prepared by centrifugation of blood samples at $2,500 \times g$ for $20 \mathrm{~min}$ at $4^{\circ} \mathrm{C}$ and quickly stored at $-80^{\circ} \mathrm{C}$ in polypropylene tubes before use. After centrifugation, plasma samples were filtered using a $0.2 \mu \mathrm{m}$ membrane.

\section{Echo-Guided Intracardiac Injection}

Mice were trichotomized using a commercial depilatory gel. The animals were positioned at a holder that has conductive plates, enabling echocardiogram registration on the chest covered with ultrasound gel by means of a VisualSonic VEVO device 770 with $30-\mathrm{MHz}$ transducer. The procedure was done under anesthesia provided by an isoflurane gas outlet while maintaining the temperature at $40^{\circ} \mathrm{C}$. Heart was visualized in cross section in height of the papillary muscles lines and a needle was aligned with the transducer to display it near the left ventricular cavity. The aligned needle penetrated the myocardium, and after aspiration to verify if the cavity was accessed, we injected the suspension of Dm28c TCTs $\left(10^{6}\right.$ parasites) or PBS solution (volume of $50 \mu \mathrm{l}$ ) in the myocardium [lateral wall of the left ventricle (LV)]. After being removed from the holder, the animals were left in their cages where they recover from anesthesia within $5 \mathrm{~min}$. Furthermore, animals were housed following the conditions described above (Mice inbred strains). At the end of the study, mice were euthanized by $\mathrm{CO}_{2}$ inhalation followed by the assessment of heart parasite load and histological analyses. Altogether, 180 mice were used.

\section{Histopathological Analyzes of Heart Tissues}

The heart tissues from C57BL/6 mice infected as described above were isolated at 30 d.p.i and processed for evaluation of leukocyte infiltrates, MCs, and collagen deposition. Hearts were removed, washed, and softly squeezed in PBS until expel the blood before being fixed in formalin $5 \%$ for $24 \mathrm{~h}$ at room temperature. Hearts (cutting in half) were transferred to the tissue cassette and dehydrated through serial $\mathrm{EtOH}$ incubation for $30 \mathrm{~min}$. They were then clarified in xylene (three times) for $30 \mathrm{~min}$ each. After $1 \mathrm{~h}$ in Erv-plast paraffin (Easypath-Brazil) at $58^{\circ} \mathrm{C}$, hearts were embedded in the same paraffin. Serial sections $(4 \mu \mathrm{m})$ were cut and after removal of the paraffin, they were incubated in serial EtOH followed by staining with H\&E, Safranin, or Picrosirius Red, to evaluate respectively infiltrating leukocytes, MCs, and collagen fibers. Sections were visualized using a LEICA scan microscope with $20 \times$ objective (H\&E, Safranin), and $20 \times$ or $10 \times$ objective (Picrosirius Red). Hearts from non-infected mice (PBS injected) were always included as controls and did not exhibit pathologic changes. Leukocyte infiltration was quantified by counting $( \pm 200$ cells in 50 fields) in the entire pericardium area and myocardium near pericardium, where they were preferentially localized. Cardiac MCs were quantified by counting Safranin positive cells in the pericardium and near the pericardium area. For collagen quantification, six sections of one of the halves were entirely photographed. Using Image Pro-Plus (Image Processing and Analysis
Software), we measured each photographed section and adjust as total area. The percentage of collagen area was calculated in relation to the total area.

\section{Measurements of $T$. cruzi DNA in the Mouse Tissues}

Trypanosoma cruzi quantification was performed as previously described by our group (30) and others (44). C57BL/6, B6-Kit ${ }^{+/+}$, and B6-kitW-sh/W-sh mice were infected according to the description above. Where indicated, the animals were treated $1 \mathrm{~h}$ prior to infection with a single-dose of: (i) cromoglycate (20 mg/kg-i.v.), (ii) B2R antagonist HOE-140 (100 $\mu \mathrm{g} / \mathrm{kg}$ - s.c.), (iii) $\mathrm{ET}_{\mathrm{A}} \mathrm{R} / \mathrm{ET}_{\mathrm{B}} \mathrm{R}$ double antagonist Bosentan $(30 \mathrm{mg} / \mathrm{kg}-\mathrm{i} . \mathrm{p}$. (45), or (iv) FXII inhibitor (4.5 mg/kg-i.v.) (36). Hearts were isolated 3 d.p.i., washed, softly squeezed in PBS until expel the blood and minced with surgical blades before DNA was isolated using the DNeasy blood and tissue Kit (QIAGEN) or PureLink genomic DNA mini Kit (Invitrogen, Carlsbad, CA, USA) according to the manufacturer's instructions. Briefly, up to $25 \mathrm{mg}$ of tissue was added to a $2 \mathrm{ml}$ sample tube with lysis Buffer and proteinase $\mathrm{K}$, mixed by gentle vortex and, subsequently, incubated at $56^{\circ} \mathrm{C}$ for $3 \mathrm{~h}$. The DNA concentration was determined using the NanoDrop ND-1000 spectrophotometer (NanoDrop Technologies). The $260 / 280$ ratio was calculated by spectrophotometer and used to evaluate the DNA purity (range between 1.8 and 2.0 was considered acceptable). Quantitative polymerase chain reaction (qPCR) for parasite quantification was performed using $100 \mathrm{ng}$ of total DNA using a T. cruzi DNA dilution (standard curve). The standards for the qPCRs were generated using DNA from T. cruzi (Dm28c) epimastigotes. Considering that one parasite contains about $100 \mathrm{fg}$ of DNA (46), we designed a curve with initial $2.5 \mathrm{ng}$ (equivalent to 25,000 parasites with $C_{\mathrm{t}}$-mean 19) and serially diluted (1:10) until the lower limit of $2.5 \mathrm{fg}(0.025$ parasites with a $C_{\mathrm{t}}$-mean 37$)$. The reactions were performed in a StepOne sequence detection system (Applied Biosystems, Warrington, UK) using SYBR Green PCR Master Mix (Applied Biosystems, Warrington, UK). The standard PCR conditions were $95^{\circ} \mathrm{C}(10 \mathrm{~min})$, and then $45 \mathrm{cycles}$ of $95^{\circ} \mathrm{C}(30 \mathrm{seg}), 60^{\circ} \mathrm{C}$ ( $1 \mathrm{~min}$ ), followed by the standard denaturation curve. Each reaction contained DNA template and $0.4 \mu \mathrm{M}$ of each T. cruzispecific primers GCTCTTGCCCACACGGGTGC (forward) and CCAAGCAGCGGATAGTTCAGG (reverse); and $0.1 \mu \mathrm{M}$ of each primer for genomic B2m, CTGAGCTCTGTTTTCGTCTG (forward) and TATCAGTCTCAGTGGGGGTG (reverse). For quantification, T. cruzi measurement (average of triplicates) was corrected using the murine B2M-product (loading control, average of triplicates).

\section{Statistical Analysis}

Data are presented as mean $\pm \mathrm{SD}$, unless otherwise indicated. The Student $t$-test and/or analysis of variance (ANOVA and Wilcoxon) were used to determine statistical significance. When the mean values of the groups showed a significant difference, pair-wise comparison was performed using the Bonferroni test. Statistical significance was set at $P<0.05$. All statistical analysis was performed with Prism 5.0 (GraphPad Software). 


\section{RESULTS}

\section{Histamine and BK Potentiate the Proinflammatory Phenotype of TCTs}

We have previously demonstrated that TCTs elicit plasma leakage via cooperation between tGPI, a mucin-linked phosphatidylinositol anchor that activates toll-like receptor 2 (TLR2) $(47,48)$ and cruzipain, a cysteine protease that releases kinins from surface bound HK and C5a from native C5 (31). More recently, studies of the pathogenesis of anaphylaxis linked severe MC-mediated reactions to $\mathrm{BK}$ release via heparin-induced activation of the contact system (10). Given this precedent, and limited information about the pathogenic role of MCs in Chagas disease $(49,50)$, we asked whether T. cruzi-induced inflammation was propagated via activation of the MC/KKS pathway. IVM in the HCP seemed to be an appropriate system to address this question because (i) MCs are predominantly positioned along arterioles of the HCP and respond to topically applied stimuli such as 48/80 (51), (ii) the pathogens are topically applied to the HCP (33), hence dispensing the use of needles-a procedure that causes bleeding and spurious KKS activation, and (iii) hamsters are susceptible to T. cruzi infection and exhibit a dilated chronic cardiomyopathy that closely resembles the human heart disease (52).

Before checking whether $T$. cruzi-induced inflammation involved activation of the MC/KKS pathway, we performed a series of mechanistic studies in a simplified model involving topic application of DXS (500 kDa) - a classical activator of the contact system (53), here used to simulate the effect of MC-derived triggers, such as heparin and polyP, both of which stored in MC granules $(11,12)$. Prior to the undertaking of IVM studies, we conduced test tube assays to verify whether addition of DXS (20 nM) to citrated hamster plasma activated the contact system, generating enzymatically active PKa. As previously shown with human plasma (42), we found (Figure 1A) that (i) DXS-treated hamster plasma promoted the hydrolysis of the BK flanking sequences of murine kininogen-1 and (ii) the enzymatic cleavage was inhibited by PKSI-527, a well-characterized PKa inhibitor (41).

Next, we checked whether the topically applied DXS $(4 \mu \mathrm{M}$; added to the superfusate) could elicit plasma leakage (FITCdextran extravasation) in the HCP via activation of the KKS. Intriguingly, DXS did not evoke significant microvascular leakage for at least $30 \mathrm{~min}$ (Figure 1B, left panel). Unexpectedly, however, we noticed a subtle extravasation in a few postcapillary venules at later time-points (Figure 1B, left panel), which then rapidly propagated throughout the entire HCP. This delayed plasma leakage elicited by DXS ( $>30 \mathrm{~min}$ ) was inhibited both by cromoglycate (Figure 1B, right panel, Figure S1 in Supplementary Material) and by HOE-140, a specific B2RA (Figure S1 in Supplementary Material). These initial results suggested that some extent of MC degranulation occurred after $30 \mathrm{~min}$ of HCP exposure to DXS $4 \mu \mathrm{M}$. Further downstream, histamine released from MCs could activate endothelial cells and, thus, enable diffusion of plasma-borne contact factors (FXII/PK/HK) through the DXS-laden HCP. Since these effects were blocked by HOE-140, we deduced that BK released at the downstream end of the proteolytic cascade could intensify and spatially propagate inflammation via iterative cycles of endothelial B2R activation, plasma leakage and MC degranulation. To test this hypothesis, we next checked whether addition of sub-optimal concentrations of DXS (10-fold lower; $0.4 \mu \mathrm{M})$ and histamine $(4 \mu \mathrm{M}$, likewise added to the superfusate) could act synergistically in the HCP. Indeed, we saw a fourfold increase $(P<0.05)$ in the maximal extravasation of plasma induced by DXS/histamine at $10 \mathrm{~min}$ (Figure 1C) as compared to the microvascular leakage evoked by histamine alone (10 min). Moreover, the leakage induced by DXS/histamine was further potentiated by addition of captopril, i.e., inhibitor of BK degradation by ACE; the presence of the ACE inhibitor led to a 12 -fold increase in maximal extravasation at $20 \mathrm{~min}$ - as compared to histamine alone $(10 \mathrm{~min}$, Figure 1C, fold increase calculated after subtraction of the baseline fluorescence). Importantly, the synergistic effects of DXS/histamine were inhibited by (i) cromoglycate, irrespective of absence (Figure 1C) or presence (Figure 1C; Figure S3 in Supplementary Material) of captopril, (ii) HOE-140 (Figure 1D), (iii) the PKa inhibitor PKSI-527 (Figure 1D), and (iv) PdSP15a (Figure 1D), a contact phase inhibitor present in the saliva of the sand fly Phlebotomus duboscai (42). To further evaluate whether MC/histamine-driven influx of plasma was the rate-limiting step governing $\mathrm{BK}$ release in DXS-HCP, we substituted the histamine "priming" step by adding an aliquot $(50 \mu \mathrm{l})$ of fresh hamster plasma (heparinized) on top of the HCP. Prior to application on the tissue, we conducted the test tube assay described above (Figure 1C) and confirmed that there was no spontaneous activation of the contact system in the hamster plasma-treated with $4 \mathrm{kDa}$ heparin. Moreover, the presence of heparin $4 \mathrm{kDa}$ did not protect the plasma from PK activation by DXS (Figure S2 in Supplementary Material). As predicted, DXS promptly induced microvascular leakage via the kinin/B2R-dependent pathway (Figure 1E). Control experiments revealed that the integrity of the endothelial barrier was preserved in HCP exposed to hamster plasma in the absence of DXS (Figure 1E).

In the next series of experiments (Figure 2), the TCTs were topically applied to the HCP jointly with a sub-optimal dose of histamine with the purpose to induce a subtle microvascular leakage in the parasite-laden tissues. As described in previous studies, the superfusion of the HCP is interrupted for a longer period $(9 \mathrm{~min})$ to allow for the diffusion/attachment of the motile flagellated parasites to the tissue stroma (see Methods). To minimize ACE/kininase II-dependent degradation of intact kinins during the period of interrupted superfusion, we routinely added the ACE inhibitor captopril to the superfusate $(29,31,38)$. As predicted, the application of TCTs to histamineprimed (suboptimal) HCPs induced leakage responses that were far more robust as compared to that induced separately by the pathogen or by histamine (Figure 2A, 328 and 1,094\%, respectively, at 15 and $20 \mathrm{~min} ; P<0.014$ and 0.037 , percentage calculated after subtraction of the baseline fluorescence). The notion that TCTs/histamine acted synergistically at 15,20 , and 25 min (Figure 2A; green versus black squares, $P<0.05$ ) was confirmed by analysis of the arithmetic sum of leakage responses from individual hamsters to histamine alone and TCTs alone. Similarly, measurements of area under the curve (up to $30 \mathrm{~min}$ ) 
A

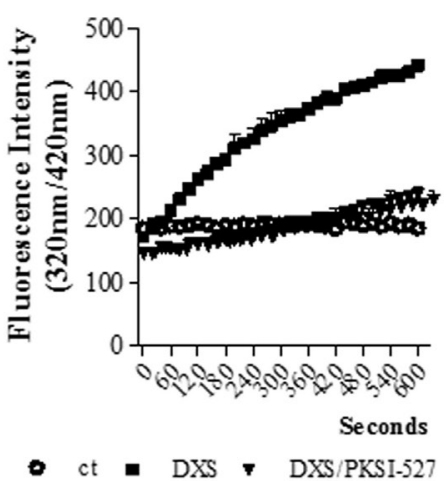

B

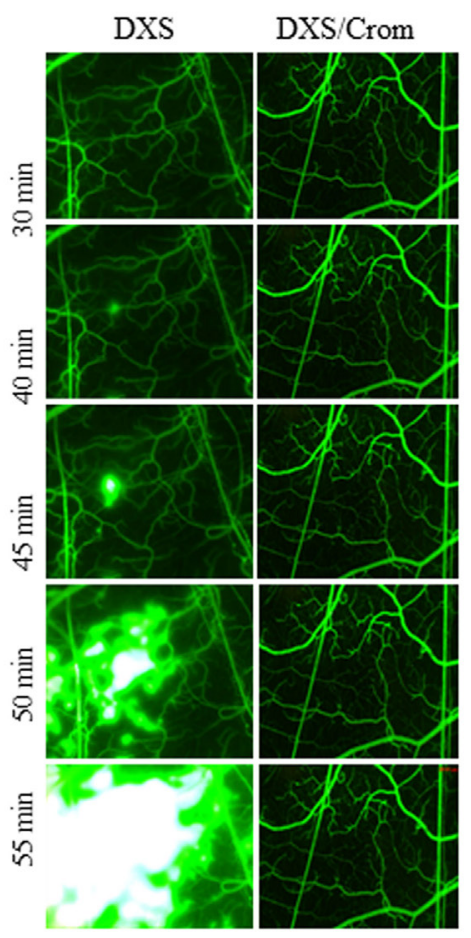

C

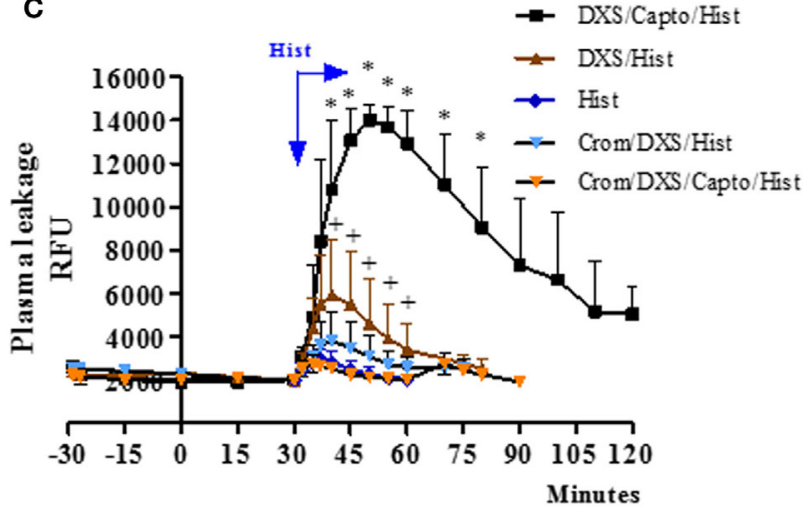

D
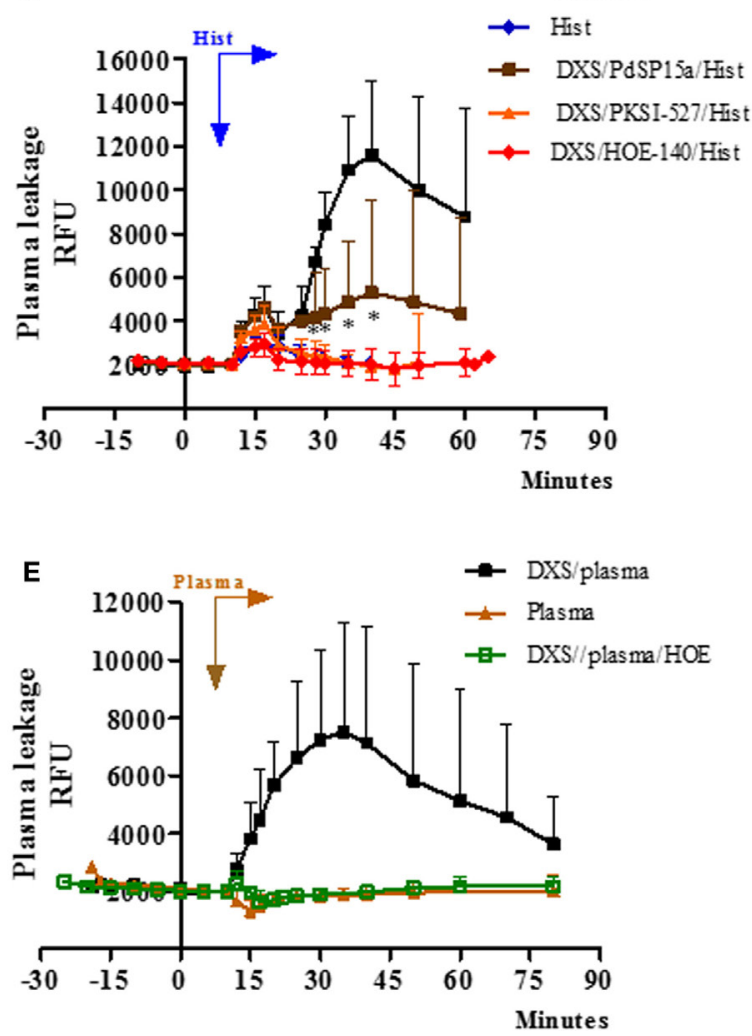

FIGURE 1 | Bradykinin-induced microvascular leakage is propagated via coupling of mast cell and contact phase factors. (A) Enzyme assays performed with high molecular weight kininogen mimetic substrate detect plasma kallikrein (PKa) activity in fresh hamster plasma (citrated) incubated with the contact activator dextran sulfate (DXS) (20 nM). The kinetics of hydrolysis was performed in the presence/absence of the PKa inhibitor PKSI-527. Substrate hydrolysis was monitored by the increase of fluorescence with time (mean \pm SD). Data are representative of three independent experiments run in duplicates. (B-E) Microvascular leakage in the hamster cheek pouch (HCP) sensitized with DXS. (B) HCPs were superfused with DXS (4 $\mu$ M) for 45 min and fluorescence was visualized at different time-points (representative images, $n=6$ ). Where indicated, the hamsters were pretreated with cromoglycate. (C) Synergism between histamine and DXS was studied after 30 min tissue superfusion, with medium supplemented with DXS $0.4 \mu \mathrm{M}$, in the presence or absence of captopril, followed by 5 min of histamine application, i.e., without any interruption of superfusion., DXS/Hist $(n=5)$, DXS/Capto/Hist $(n=5)$. Where indicated, the hamsters were pretreated i.p. with cromoglycate ( $n=2$, and $n=4$, in the presence and absence of captopril, respectively). Histamine-induced leakage ( $n=12$ ) was inserted (internal controls) for comparison. (D) Evidence that synergism between DXS/histamine leads to leakage via activation of the kallikrein-kinin system was sought in HCP superfused for 10 min with DXS (2 $\mu$ M) and captopril, followed by 5 min of superfusion with DXS/histamine application $(n=9)$. Prior to the application of histamine, the DXS-treated HCPs were either treated (superfusion interrupted) with the contact phase inhibitor PdSP15a $(n=6)$ or with PKa inhibitor PKSI-527 $(n=5)$ for 5 min. HOE-140 ( $n=4)$, the B2R antagonist (B2RA) was applied together with DXS + Captopril. (E) For plasma reconstitution experiments, HCPs were superfused with DXS + Captopril for 10 min, followed by topical application (superfusion interrupted) of heparinized hamster plasma for 7 min. Plasma $(n=5)$, and DXS/plasma $(n=8)$. HOE-140 ( $n=4)$ was applied along with DXS + Captopril before addition of plasma. Data are expressed as: (C-E) Relative fluorescence units (RFUs) (mean \pm SD). Statistical analyzes were done by analysis of variance and $t$-test. In (C), ${ }^{\star} P<0.05$ DXS/Capto/Hist versus DXS/Hist and $+P<0.05$ for DXS/Hist versus DXS/Crom/Hist and D, ${ }^{\star} P<0.05$ DXS/ PdSP15a/Hist versus DXS/Hist. 


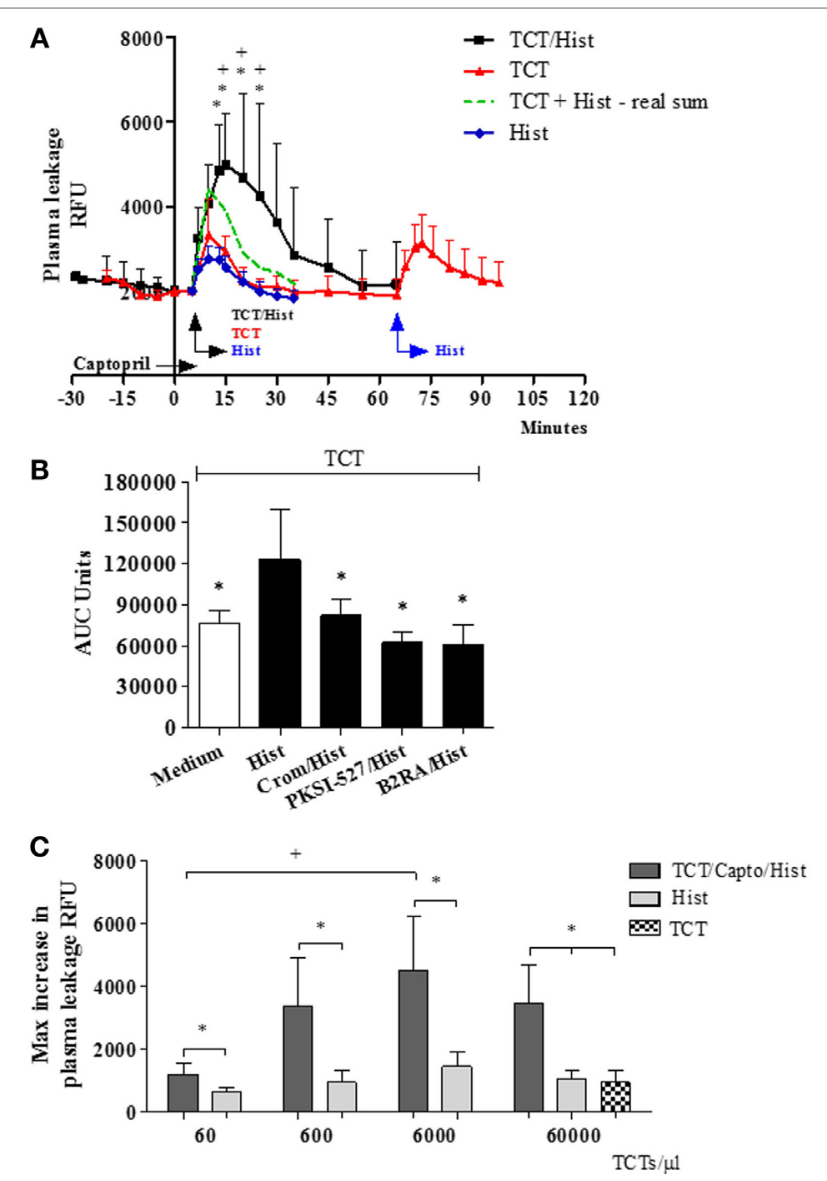

FIGURE 2 | A subtle destabilization of the endothelial barrier potentiates infection-associated inflammation. (A-C) Hamster cheek pouches (HCPs) were superfused with captopril for $10 \mathrm{~min}$, followed by application of histamine $(4 \mu \mathrm{M})$ along with tissue culture trypomastigotes (TCTs) $\left(3 \times 10^{7}\right)$ during 10 min of interrupted superfusion $(n=12)$. TCT control group $(n=8)$ involved $\mathrm{HCP}$ treatment with captopril in the absence of histamine. Prior to TCT/histamine application, pharmacological interventions were performed with cromoglycate (pretreatment, $n=6$ ); HOE-140 (B2RA; $n=5$ ) and PKSI-527 ( $n=5)$, applied for $5 \mathrm{~min}$. In A at 60 min after TCT application histamine $4 \mu \mathrm{M}(n=8)$ was applied as an internal control and these values were then added to the TCT values (real sum - green curve) and used for the calculation of a synergistic effect of histamine and TCT. Results of histamine $4 \mu \mathrm{M}(n=10)$ applied to HCPs in steady state were inserted as a secondary control. Data are expressed as follows: (A) relative fluorescence units (RFUs) over time (mean $\pm \mathrm{SD})$, (B) area under the curve $(A \cup C \pm S D)$ measured during $30 \mathrm{~min}$. Statistical analysis were done by analysis of variance (ANOVA) and Wilcoxon. In (A) ${ }^{*} P<0.05$ (TCT/Hist versus TCT) and $+P<0.05$ (TCT/ Hist versus real sum). In (B) ${ }^{\star} P<0.05$ (TCT/Hist versus TCT or TCT/Hist/ inhibitor/antagonist) (C) HCPs were superfused with captopril for $10 \mathrm{~min}$, followed by topical application of different doses of TCTs $(60,600,6,000$, and 60,000 TCTs/ $\mu \mathrm{l})$ and histamine $(n=4)$ during $10 \mathrm{~min}$ of interrupted superfusion (dark gray). At 60 min after TCT application, histamine was applied during $5 \mathrm{~min}$ as a control (light gray). Data are expressed as maximal increase in RFU (mean $\pm \mathrm{SD}$ ). Statistical analyzes were done by ANOVA and Wilcoxon ( ${ }^{\star} P<0.05$, TCT/Capto/Hist versus histamine; TCT/Capto/Hist versus TCT; ${ }^{+} P<0.05$, TCT 60/Capto/Hist versus TCT 6000/Capto/Hist).

showed that the spatial propagation of inflammation observed in histamine-primed HCPs exposed to TCTs was abolished by: (i) B2RA (HOE-140), (ii) cromoglycate, and (iii) the PKa inhibitor PKSI-527 (Figure 2B, $P<0.05$ ). We reached the same conclusion using the peak of macromolecular leakage as the criteria (Figure S4 in Supplementary Material, $P<0.05$ ). Control experiments, i.e., performed in the absence of TCTs, showed that plasma leakage induced by histamine alone $(4 \mu \mathrm{M})$ was not potentiated by captopril, nor was it inhibited by HOE140, PKSI-527 or cromoglycate (Figure S5 in Supplementary Material). Finally, histamine-sensitized HCPs were topically exposed to decreasing doses of TCTs in order to determine the minimal load of pathogen that was capable of evoking a significant leakage. Our results (Figure 2C) showed that a 100fold lower load (corresponding to $600 \mathrm{TCTs} / \mu \mathrm{l}$ ) still caused a statistically significant increase in plasma leakage $(P<0.05)$ as compared with histamine alone. Collectively, our studies suggest that tissues with leaking postcapillary venules might potentiate the proinflammatory phenotype of trypomastigotes via activation of BK-induced feedback loops forged by $\mathrm{MC}$ coupling to the KKS.

\section{T. cruzi Elicits Paw Edema via Activation of the MC/KKS Pathway}

Although the studies in the HCP provided a framework to investigate the impact of plasma leakage on the proinflammatory phenotype of T. cruzi, the anesthetized hamsters must be sacrificed at the end of the IVM experiments ( $\sim 60 \mathrm{~min})$, thus precluding an analysis of the pathogenic outcome at later time points. Turning to mice models of infection, we next injected Dm28c TCTs in the footpad of B6-KitW-sh/W-sh (MC-deficient) and B6-Kit ${ }^{+/+}$mice. Edema measurements $(3 \mathrm{~h})$ revealed a prominent edema in WT mice (Figure 3A) and a negligible paw response in the mutant strain (Figure 3A). Internal controls in MC-competent mice showed that the edema was inhibited by HOE-140 (B2RA) (72\%, $P<0.05)$ (Figure 3A). We next pretreated WT mice with cromoglycate, and found that this classical MC stabilizer inhibited the infection-associated edema $(49 \%, P<0.05)$ even in animals that received captopril (Figure 3B). Noteworthy, cromoglycate did not inhibit inflammation as efficiently as HOE-140 at this early time point ( $3 \mathrm{~h}$ ) (Figure 3B, left panel) but the protective effects of these two drugs equalized at $24 \mathrm{~h}$ p.i. (Figure 3B, right panel). Similarly, mepyramine (antagonist of histamine $\mathrm{H} 1$ receptor, H1RA) partially inhibited TCT-evoked swelling both at 3 and $24 \mathrm{~h}$ p.i. (67\%, $P<0.05$, and $83 \%, P<0.05$, respectively; Figure 3B). To verify whether TCTs evoked B2R-dependent edema via MC coupling to the contact system, we next pretreated BALB/c mice with infestin-4, a recombinant protein recently characterized as a specific inhibitor of FXIIa (36). Indeed, infestin-4 drastically inhibited TCT-induced swelling $(75 \%, P<0.05)$ (Figure 3C), thus further suggesting that activation of the BK/B2R pathway propagates the inflammatory response orchestrated via the contact pathway.

\section{Intracardiac Activation of the MC/KKS Pathway Fuels Heart Parasitism and Infection-Associated Myocarditis/Fibrosis}

Given pieces of evidence that BRs and ETRs serve as gateways for T. cruzi invasion of cardiovascular cells in vitro $(13,27,33)$, 

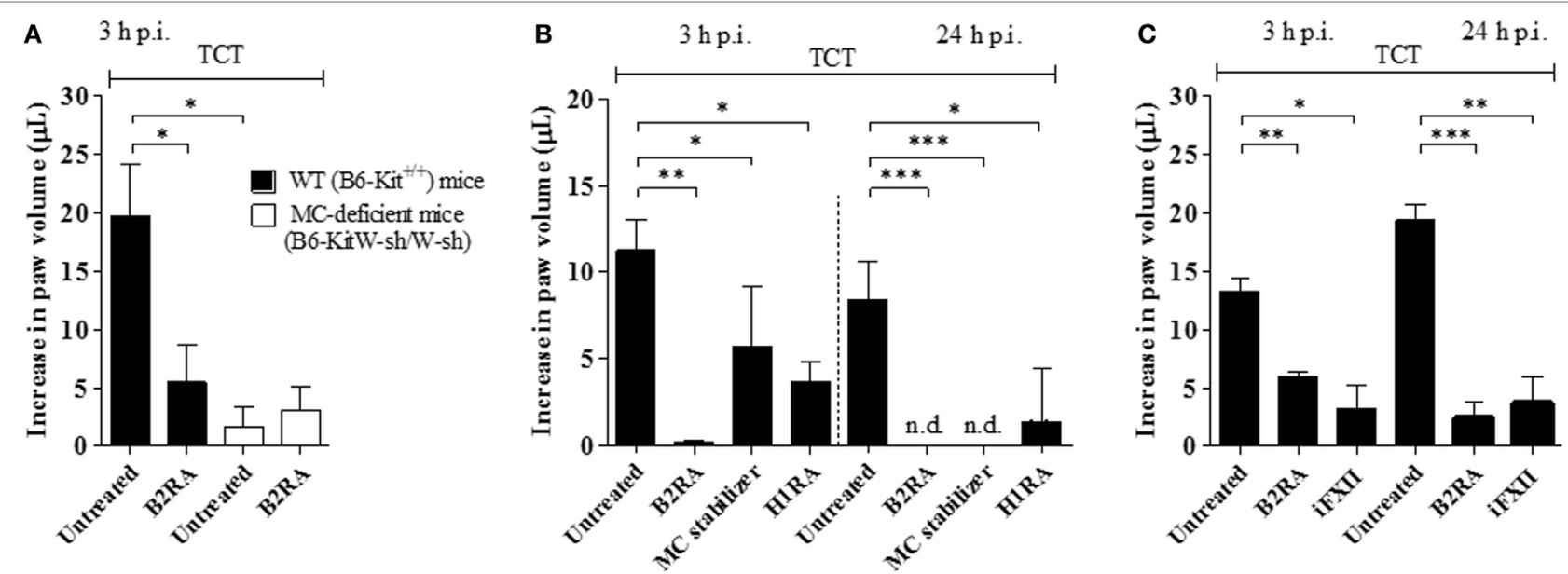

FIGURE 3 | Tissue culture trypomastigotes (TCTs) evoke paw edema via the mast cell (MC)/kallikrein-kinin system pathway. (A) WT (B6-Kit ${ }^{+/+}$) or MC-deficient mice (B6-kitW-sh/W-sh) were infected with TCTs $\left(10^{6}\right)$. The contralateral paw received PBS. When indicated, mice were pretreated $(-1 \mathrm{~h})$ with the B2R antagonist $(\mathrm{B} 2 \mathrm{RA})$ (HOE-140). (B,C) Infected BALB/c mice were pretreated (-1 h) with HOE-140, cromoglycate (MC stabilizer), histamine H1 receptor (H1R) antagonist (mepyramine) or factor XII (FXII) inhibitor (infestin-4). Captopril was used (i.p.) to inhibit kinin degradation. Edema was measured at 3 and $24 \mathrm{~h}$ and results are expressed as difference in volume $(\mu l)$ between infected and contralateral paw (mean $\pm \mathrm{SD}$ ). Data are representative of three independent experiments (five mice/group). Statistical analyzes were done by analysis of variance with Bonferroni post test $\left({ }^{\star} P<0.05 ;{ }^{\star \star} P<0.01,{ }^{\star \star \star} P<0.001\right)$.

here we asked whether intracardiac activation of the MC/KKS pathway could promote parasite infectivity by fostering the proteolytic release of kinins and endothelins, which could then act as infection-promoting signals in heart tissues. Assisted by high-resolution echocardiography, we injected TCTs (Dm28c) directly in the LV of the heart of WT and MC-deficient mice. Heart parasite load (replicating amastigotes) was evaluated 3 d.p.i. by quantifying T. cruzi DNA by qPCR. In the second group of experiments, intracardiac challenge with TCTs was performed in WT mice that were pretreated $1 \mathrm{~h}$ earlier with (i) cromoglycate, (ii) infestin-4, (iii) HOE-140, and (iv) bosentan (double antagonist of $\mathrm{ET}_{\mathrm{A}} \mathrm{R} / \mathrm{ET}_{\mathrm{B}} \mathrm{R}$ ). Noteworthy, here (unlike the experimental conditions used in the footpad model of infection), the animals were not pretreated with captopril-thus preserving the kinin-degrading function of ACE as well as its competence to convert angiotensin I into the vasoconstrictor angiotensin II in the cardiovascular system. At different time-points (see timeline, Figure 4), we examined extent of heart parasitism (3 d.p.i.) and pathological outcome (histopathology, 30 d.p.i.). Strikingly, we observed that the parasite load in heart tissues declined in WT mice pretreated by HOE-140 (B2RA) (Figures 4A,D; respectively 71 and $76 \%, P<0.001)$ or bosentan $\left(\mathrm{ET}_{\mathrm{A}} \mathrm{R} / \mathrm{ET}_{\mathrm{B}} \mathrm{R}\right.$ Antag, Figure 4A, 80\%, $P<0.001)$. Having established that these GPCR blockers redundantly inhibited intracardiac parasitism in WT mice, we next asked whether cardiac MCs were implicated in this process. First, we compared the levels of parasite DNA in the heart of MC-deficient B6-KitW-sh/W-sh mice versus MC-competent mice. Notably, the parasite load (3 d.p.i.) was sixfold lower in the hearts of the MC-deficient strain as compared to the WT controls (Figure 4B). Given technical difficulties to reconstitute the heart of MC-deficient mice with bone marrow-derived progenitor cells, we re-addressed this question by subjecting WT mice to pharmacological treatment with the
MC stabilizer cromoglycate. Consistent with the protective phenotype of MC-deficient mice, we found that heart parasitism (Figure 4C) was sharply reduced in cromoglycate-treated mice (78\%, $P<0.05)$. Noteworthy, control experiments performed with cromoglycate (tested in vitro at a concentration equivalent to that present in the bloodstream) confirmed that this MC stabilizer did not impair T. cruzi infection of primary mouse heart cells (Figure S6 in Supplementary Material). We next pretreated WT mice with the FXIIa inhibitor infestin- 4 and verified that the intracardiac levels of T. cruzi DNA (Figure 4D; 97\%, $P<0.01$ ) were sharply decreased.

Next, we performed histopathological studies to determine whether the early cardioprotective effects promoted by the GPCR antagonists attenuated heart pathology. Not surprisingly, histopathology performed at 30 d.p.i. revealed that myocarditis/ fibrosis was intense in the control infected mice (Figure 5). Interestingly, the elevated infiltration of leukocytes in chagasic mice was accompanied by increased density of intracardiac MCs (Figure 5). Strikingly, we found a significant reduction in the numbers of heart-inflammatory infiltrating leukocytes and of density of intracardiac MCs in T. cruzi-infected mice pretreated with B2RA (HOE-140) or $\mathrm{ET}_{\mathrm{A}} \mathrm{R} / \mathrm{ET}_{\mathrm{B}} \mathrm{R}$ Antag. (bosentan) (Figure 5A, leukocytes; respectively, 34\%, $P<0.05$; and $82 \%$, $P<0.001-\mathrm{MC}$ density; respectively, $45 \%, P<0.01 ; 80 \%, P<0.01$; Figure 5B). Examination of heart fibrosis at the same time-points again confirmed that these GPCR antagonists were redundantly cardioprotective: the deposition of collagen was markedly attenuated in mice pretreated either with B2RA or with the double $\mathrm{ET}_{\mathrm{A}} \mathrm{R} / \mathrm{ET}_{\mathrm{B}} \mathrm{R}$ blocker (Figure 5C, respectively 73\%, $P<0.05 ; 85 \%$, $P<0.05)$. Collectively, our studies suggest that excessive intracardiac activation of the MC/KKS pathway fueled T. cruzi parasitism and worsened myocarditis/fibrosis via proteolytic generation of kinins and endothelins. 

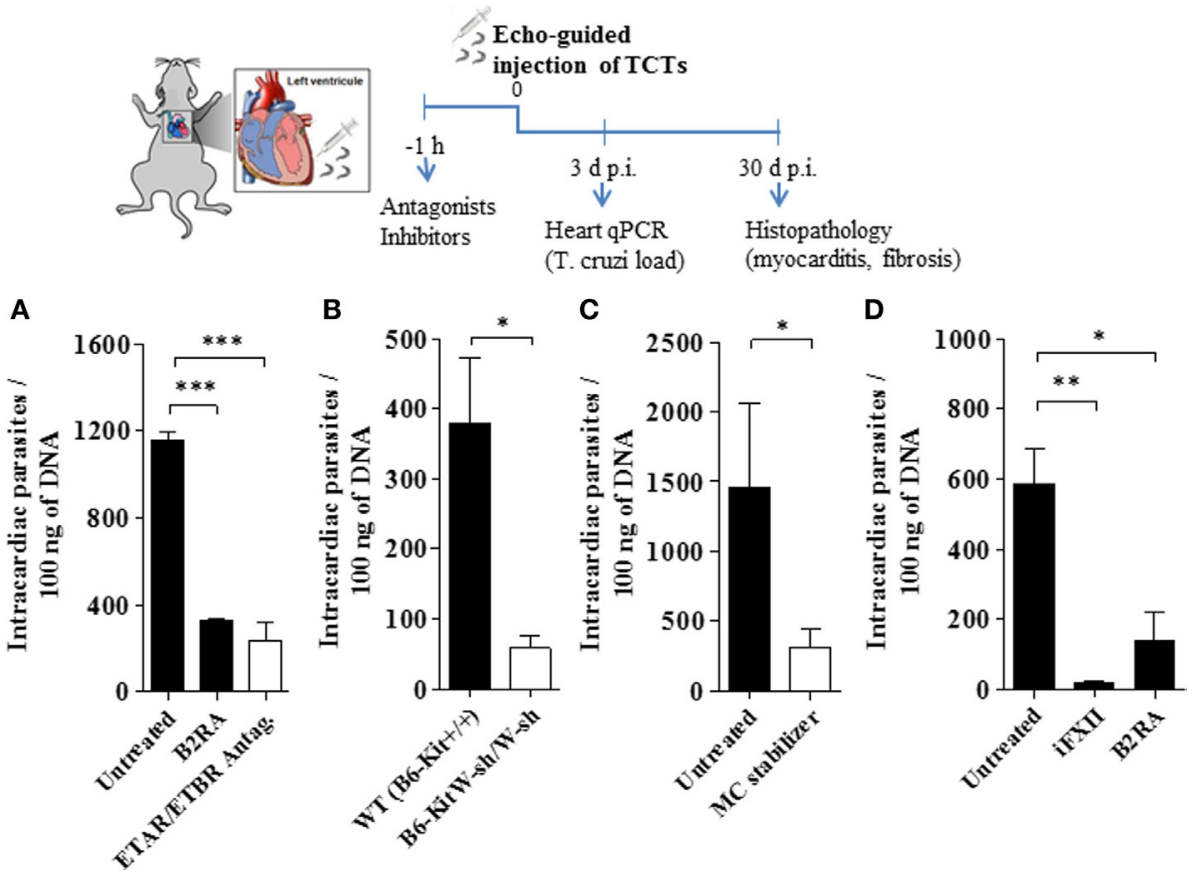

FIGURE 4 | Activation of the kallikrein-kinin system fuels heart parasitism. Measurements of Trypanosoma cruzi DNA (3 d.p.i.) in the heart of C57BL/6 infected [10 ${ }^{6}$ tissue culture trypomastigotes (TCTs)] intracardiacally (A,C,D), WT (B6-Kit ${ }^{+/+}$) mice or mast cell deficient (B6-kitW-sh/W-sh) mice (B). Where indicated, the mice were pretreated with cromoglycate, B2R antagonist (B2RA) (HOE-140), endothelin A receptor (ET ${ }_{A} R$ )/endothelin $B$ receptor (ET $B$ ) double antagonist (bosentan) or factor XII (FXII) inhibitor (infestin-4). Results (mean \pm SD) of $T$. cruzi DNA by quantitative polymerase chain reaction (qPCR) are representative of two independent experiments (five mice/group). Statistical analyzes were done by analysis of variance with Bonferroni post test ${ }^{\star} P<0.05$; ${ }^{\star \star} P<0.01$, ${ }^{\star \star \star} P<0.001$ ).

\section{DISCUSSION}

Standard definitions of immune subversion are built on the assumption that pathogens exploit host cell metabolism and shifts in immunoregulatory responses to survive in hostile environment. Although we have previously demonstrated that activation of the proinflammatory kinin/B2R pathway generates immunoprotective IFN- $\gamma$-producing effector T cells against T. cruzi (30), here we provide evidence that T. cruzi reciprocally benefits from the intracardiac activation of the $\mathrm{MC} / \mathrm{KKS}$ pathway: acting jointly with endothelins, kinins enhance tissue parasitism via activation of B2R.

Since chronic Chagas disease last several years, occasional fluctuations in immunoregulation may favor intracellular parasite outgrowth in scattered heart cells. Sporadically, a few heavily parasitized host cells rupture, swarming the surrounding tissues with infective trypomastigotes. Within minutes, the endothelial barrier might open in response to endogenous alarmins and/or proinflammatory molecules shed from the trypomastigote surface (Figure 6). It is still unclear whether the genetic diversification of the T. cruzi species contributes to the clinical pleiomorphism of CCC (54). Of interest in this context, the expression levels of proinflammatory galactosyl-bearing lipid anchors (55) vary within the genetically diversified T. cruzi species. In previous studies performed with the Dm28c strain $(29,31,33,38)$, we demonstrated that Dm28c TCTs (but not avirulent Dm28c epimastigotes) evoke a subtle endothelial barrier destabilization via a trans-cellular activation pathway (TLR2/CXCR2/ET $\mathrm{A}_{\mathrm{A}} / \mathrm{ET}_{\mathrm{B}} \mathrm{R} /$ $\mathrm{B} 2 \mathrm{R} / \mathrm{C} 5 \mathrm{aR}$ ) initiated by tGPI (TLR2 ligand) and amplified by the kinin-releasing activity of cruzipain (see scheme on Figure 6). In this paper, we showed evidence that the trans-endothelial diffusion of plasma-here sought through the activation of the MC/ KKS pathway-enhances both the proinflammatory phenotype and infectivity of Dm28c TCTs. In order to simulate tissues irrigated by "leaky" microvessels, we added sub-optimal doses of histamine jointly with the topically applied TCTs. As predicted, the microvascular leakage response evoked by TCTs was potentiated by BK-induced inflammatory cascades coordinated via the $\mathrm{MC} / \mathrm{KKS}$ pathway. Although the roles of MC-derived polyP/ heparin were not directly investigated here, the mechanistic insight that inspired this study came from simplified model studies performed with DXS, a potent activator of the contact system (53). Unexpectedly, the topically applied DXS did not induce any microvascular alterations in steady-state HCP for at least $30 \mathrm{~min}$; thereafter, however, a few localized "leaks" appeared, triggering a $\mathrm{MC} / \mathrm{KKS}$ (contact phase) driven inflammatory response that rapidly spread throughout the HCP. Combined, the IVM studies with DXS and TCTs support a linear model of BK-induced opening of the endothelial barrier initiated by a subtle influx of plasma contact factors. Assays performed with different contact phase inhibitors suggest that $\mathrm{BK}$, once liberated by $\mathrm{PKa}$, triggers iterative cycles of endothelial (B2R) activation, plasma leakage, $\mathrm{MC}$ degranulation, and PolyP/heparin-induced activation of contact factors (Figure 6). 

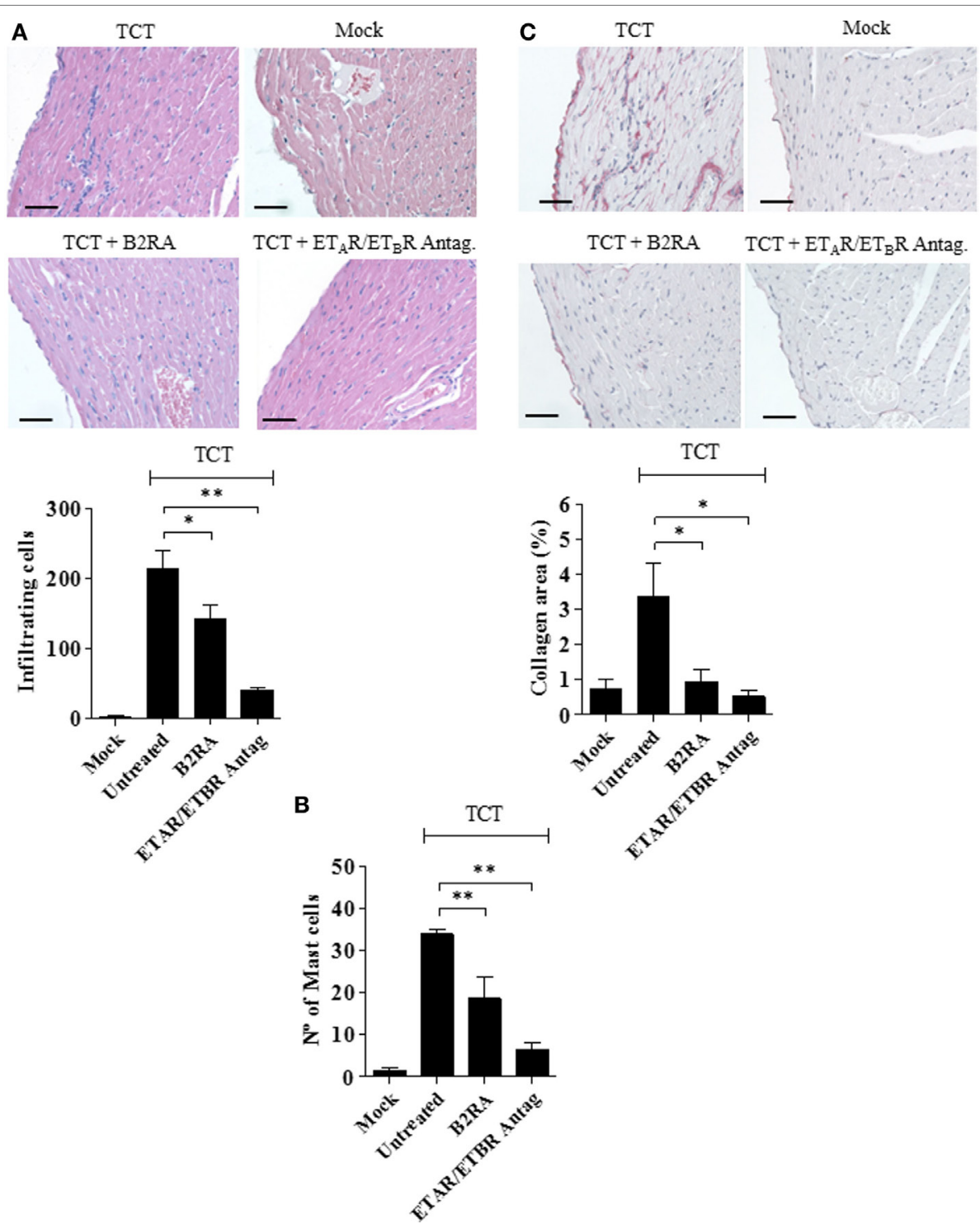

FIGURE 5 | Early targeting of BRs and ETRs inhibit myocarditis/fibrosis. C57BL/6 mice were infected intracardiacally with tissue culture trypomastigotes (TCTs)

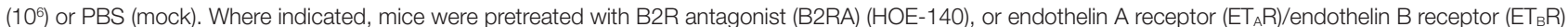
antagonist (bosentan). At 30 d.p.i., heart sections were stained with (A) hematoxylin and eosin for cellular infiltration, (B) Safranin for mast cell detection, or

(C) Picrosirius Red for collagen deposition. Bars, $50 \mu \mathrm{m}$. Data (mean $\pm \mathrm{SD}$ ) are representative of four independent experiments (five mice/group). Statistical analyzes were done by analysis of variance $\left({ }^{\star} P<0.05 ;{ }^{\star \star} P<0.01,{ }^{\star \star \star} P<0.001\right)$.

In the second part of this paper, we studied the pathogenic role of the MC/KKS pathway using two different mouse models of infection. Congruent with the IVM data generated in the HCP, we first showed that TCTs induced footpad edema via activation of BK/B2R-inflammatory cascades (orchestrated via the MC/KKS pathway). Extending these studies to the cardiac settings, we next inoculated TCTs in the heart of WT or MC-deficient mice and measured T. cruzi DNA levels at 3 d.p.i. These experiments revealed that intracardiac parasitism was markedly reduced in MC-deficient mice or, alternatively, in cardiac tissues of WT mice pretreated either with (i) cromoglycate (ii) infestin-4 (iii) HOE-140 or (iv) bosentan (non-selective $\mathrm{ET}_{\mathrm{A}} \mathrm{R} / \mathrm{ET}_{\mathrm{B}} \mathrm{R}$ antagonist). Based on these findings, we inferred that targeting of the MC/KKS pathway stabilized the endothelial barrier, hence ultimately reducing the levels of infection-promoting signals (kinins and endothelins) generated in the parasite-laden heart tissues (Figure 6). It remains to be determined whether the GPCR blockers HOE-140 and bosentan inhibited parasite infectivity by acting as endothelial barrier stabilizers, and/or acted further downstream, directly blocking GPCR-mediated uptake of TCTs (Figure 6) as originally documented in culture systems (13, $27,32,33)$. Another possibility is that T. cruzi infection is fueled by ROS (56), presumably reflecting synergism between innate immunity (TLR2/CXCR2 pathway) (38) and the short-lived proinflammatory polypeptides generated further downstream, such as kinins and ET-1. The latter hypothesis is consistent with 


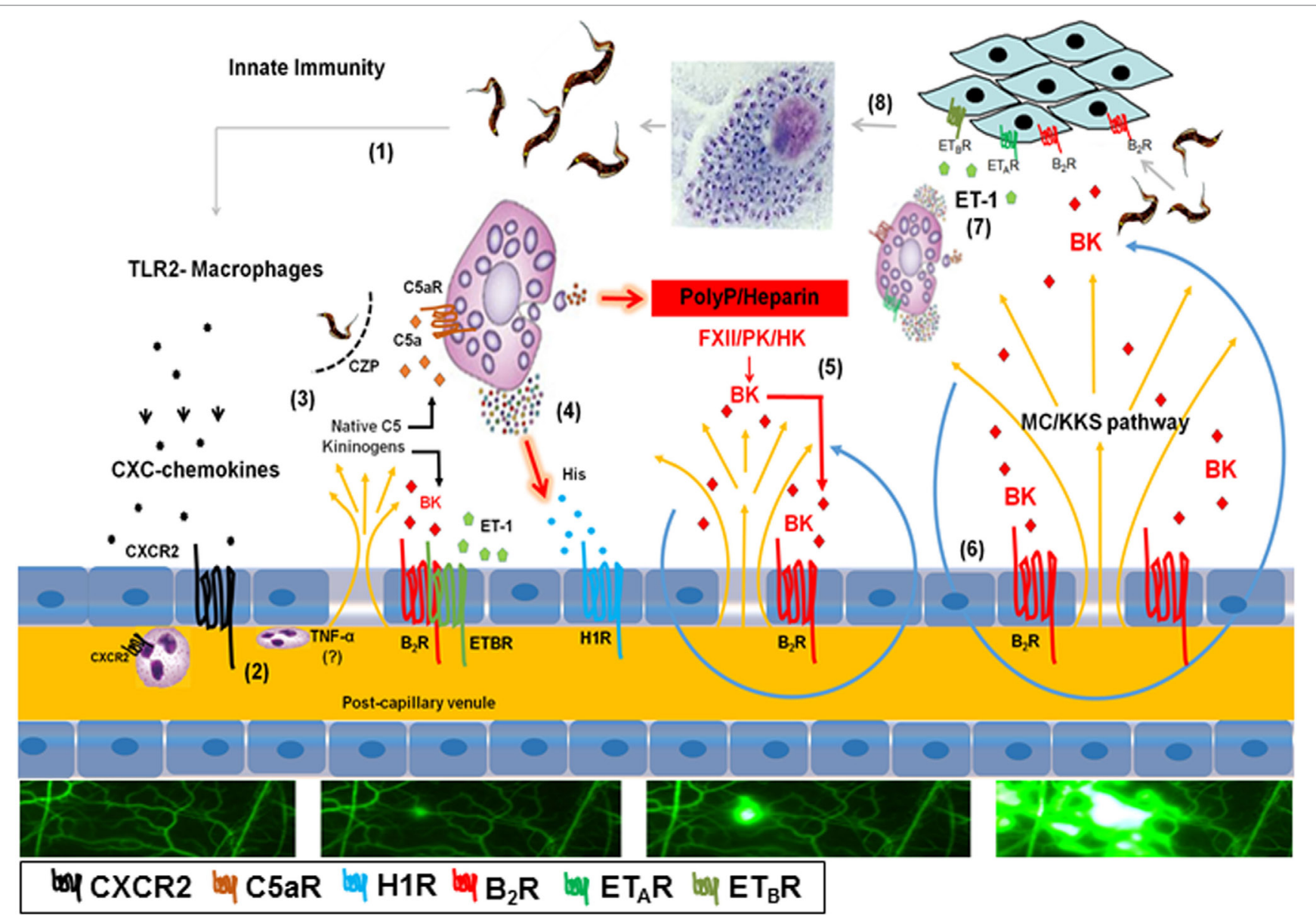

FIGURE 6 | Endothelial barrier breakdown via the mast cell (MC)/kallikrein-kinin system (KKS) pathway fuels Trypanosoma cruzi infectivity: working hypothesis. (1) Tissue culture trypomastigotes liberated from ruptured pseudocysts initiate inflammation upon sensing by toll-like receptor 2 (TLR2)-expressing tissue macrophages. (2) Secreted CXC chemokines evoke a subtle plasma leakage following CXCR2-dependent activation of endothelium/neutrophils (29, 38); although not explored in this infection model, it has been reported that TNF- $\alpha$ (57) is critically involved in neutrophil-evoked plasma leakage. (3) The diffusion of plasma proteins, including native C5 and kininogens, leads to cruzipain-mediated release of kinins and C5a anaphylatoxin in the parasite-laden tissues (31). (4) Results presented in the current work suggest that cardiac MCs activated by C5a and/or endothelin-1 (not shown in this part of the illustration) release histamine/polyphosphates (PolyP) (contact system activators) from their granules. (5) Activation of histamine $\mathrm{H} 1$ receptor (H1R) leads to the exposure of plasma-borne contact factors [factor XII (FXII), high molecular weight kininogen (HK) and plasma prekallikrein] to heparin/PolyP. Further downstream, the activated contact factor plasma kallikrein (PK) releases bradykinin (BK) from HK. (6) BK propagates the leakage response temporally and spatially via iterative cycles of endothelial [bradykinin B2 receptor (B2R)] activation (BK/B2R pathway), plasma leakage, MC degranulation, and contact system activation (MC/KKS pathway). (7) Acting jointly with endothelin-1 (ET-1), the released kinins fuel T. cruzi infectivity by signaling heart cells that naturally overexpress B2R (13) and $E T_{A} R /$ endothelin $B$ receptor (ET $B$ ) (33). (8) After endocytic internalization, the flagellated trypomastigotes transform into amastigotes which undergo multiple cycles of binary division in the host cell cytoplasm before transforming into infective trypomastigotes.

the view that plasma membrane lesions evoked by ROS (fueled by kinins and endothelins) might trigger a house-keeping mechanism of membrane repair $\left(\mathrm{Ca}^{2+} /\right.$ acid sphingomyelinase/ceramide pathway) that drives T. cruzi internalization into ceramide-rich endocytic vesicles-as originally proposed by Ref. (45).

Although not addressed here, it will be interesting to determine whether parasitized heart cells in our intracardiac model of infection upregulate ET-1 expression in our controls (i.e., in the absence of pharmacological intervention on the $\mathrm{MC} / \mathrm{KKS}$ pathway) as documented in conventional models of Chagas heart disease (26). If confirmed, it will be necessary to evaluate whether ET-1 secretion in T. cruzi-infected heart tissues depends on the innate recognition of intracellular parasites (amastigotes).
In principle, this mechanism may either involve (i) TLR9, recently defined as a sensor of unmethylated $\mathrm{CpG}$ motifs of T. cruzi DNA (58) (ii) TLR7, activated by parasite-derived RNA (59) and/or activation of NLRP3 inflammassome (60).

Lessons coming from studies of innate immunity in models of heart injury induced by pressure overload (61) might provide clues to understand the mechanism underlying the cardioprotective effects of GPCR blockers documented in our study. Using DNAse II-deficient mice, the above-mentioned authors verified that, under these stressful conditions, the excessive accumulation of host mitochondrial DNA (symbiont-like) in autolysosomes upregulates inflammation via activation of TLR9. In principle, it is possible that TLR9-dependent sensing of T. cruzi DNA 
(amastigotes) might upregulate ET-1 secretion. In mice pretreated with HOE-140 or bosentan, the intracardiac load of $T$. cruzi parasites was markedly reduced. Thus, it is conceivable that the pharmacological targeting of the MC/KKS pathway reduced intracardiac inflammation and tissue parasitism to levels that are beyond the threshold required to upregulate ET-1 via activation of innate receptors. Consistent with this viewpoint, studies of MC function in other models of heart inflammatory diseases appointed cardiac MCs as central player in cardiac remodeling (62). Our findings that the density of intracardiac MCs (30 d.p.i.) was increased in mice subjected to intracardiac challenge with T. cruzi is congruent with clinical evidence showing that (i) MC density is increased in heart tissues from HIV-reactivated CCC patients (63). Although our intracardiac model of (acute) infection is admittedly artificial, it was surprising that severity of myocarditis and heart fibrosis in WT mice (evaluated at 30 d.p.i.) was blunted in animals that were pretreated either with $\mathrm{B} 2 \mathrm{R}$ or $\mathrm{ET}_{\mathrm{A}} \mathrm{R} /$ $\mathrm{ET}_{\mathrm{B}} \mathrm{R}$ antagonists. Intriguingly, the density of cardiac MCs was also reduced in WT mice that were subjected to the single-dose treatment with these GPCR blockers at the time of intracardiac challenge. Combined, these results suggest that endothelins/ kinins, acting jointly, might upregulate trans-endothelial migration of MC precursors and/or enhance MC maturation following recruitment to the parasitized heart tissues. Future studies may clarify whether cardiac MCs activated by ET-1 may interconnect intracellular innate responses (orchestrated by TLRs and/ or inflammassome) to the proteolytic circuitry that propagates inflammation and heart fibrosis via the KKS. While these pathogenic processes are in march in chagasic patients, it is possible that the sporadic formation of inflammatory edema may provide T. cruzi trypomastigotes with an opportunity to invade heart cells that naturally overexpress bradykinin and endothelin receptors. In summary, by studying the impact infection-associated microvascular leakage on the pathogenesis of T. cruzi infection, our study provides a new mechanistic framework to investigate the role of proteolytic networks, such as the KKS, on host/parasite balance in Chagas heart disease.

\section{ETHICS STATEMENT}

All animal care and experimental procedures were performed in accordance to the Brazilian guidelines (Brazilian Directive

\section{REFERENCES}

1. Scharfstein J. Kinins. 1st ed. In: Parnham MJ, editor. Compendium of Inflammatory Diseases. Basel: Spinger (2016). p. 815-36.

2. Kaplan AP, Joseph K. Pathogenic mechanisms of bradykinin mediated diseases: dysregulation of an innate inflammatory pathway. Adv Immunol (2014) 121:41-89. doi:10.1016/B978-0-12-800100-4.00002-7

3. Müller F, Mutch NJ, Schenk WA, Smith SA, Esterl L, Spronk HM, et al. Platelet polyphosphates are proinflammatory and procoagulant mediators in vivo. Cell (2009) 139(6):1143-56. doi:10.1016/j.cell.2009.11.001

4. Oehmcke S, Morgelin M, Herwald H. Activation of the human contact system on neutrophil extracellular traps. J Innate Immun (2009) 1(3):225-30. doi:10.1159/000203700

5. Leeb-Lundberg LM, Marceau F, Muller-Esterl W, Pettibone DJ, Zuraw BL. International union of pharmacology. XLV. Classification of the kinin receptor for Care and Use of animals for Teaching and ResearchDBCA) published by the Brazilian Council for Control of Animal Experimentation (Conselho Nacional de Controle de Experimentação Animal-CONCEA, http://www.mct.gov.br/ upd_blob/0234/234054.pdf) and Federal Law 11.794 (October $8,2008)$. Studies involving animals are reported in compliance with the ARRIVE guidelines $(27,28)$. The protocols used in this study were approved by the Institutional Ethical Committee of Federal University of Rio de Janeiro (code number: IBCCF 101, and license protocol number 014).

\section{AUTHOR CONTRIBUTIONS}

$\mathrm{CN}, \mathrm{DA}, \mathrm{AO}$, and ES designed and performed experiments, analyzed, and interpreted data. CC-P conducted histopathological analysis of heart tissues. LV performed enzymatic essays. GB performed echo-guided intracardiac injection. ER and JM performed and analyzed heart parasitism. RS and LA performed animal experimentation. $\mathrm{CN}, \mathrm{DA}, \mathrm{RS}, \mathrm{LV}, \mathrm{AC}, \mathrm{AO}$, and ES also helped with the writing and edition of the manuscript. MA, MCS, LJ, PA, and AC contributed providing research tools. FS performed statistical analysis. JS conceived the study and wrote the manuscript.

\section{ACKNOWLEDGMENTS}

We would like to thank Fabio Fortes and Leandro Vairo for technical help, and Dr. Regina Goldenberg for advice on the implementation of the intracardiac model of infection. We also wish to thank Professor Luiz R. Travassos (UNIFESP) for helpful comments on the early versions of this complex manuscript.

\section{FUNDING}

This work was supported by: CAPES, FAPERJ, CNPq, DECIT, Instituto Nacional de Biologia Estrutural e Bio-Imagem (INBEB).

\section{SUPPLEMENTARY MATERIAL}

The Supplementary Material for this article can be found online at http://journal.frontiersin.org/article/10.3389/fimmu.2017.00840/ full\#supplementary-material.

family: from molecular mechanisms to pathophysiological consequences. Pharmacol Rev (2005) 57(1):27-77. doi:10.1124/pr.57.1.2

6. Zhang X, Tan F, Zhang Y, Skidgel RA. Carboxypeptidase M and kinin B1 receptors interact to facilitate efficient b1 signaling from B2 agonists. J Biol Chem (2008) 283(12):7994-8004. doi:10.1074/jbc.M709837200

7. Ahluwalia A, Perretti M. Involvement of bradykinin B1 receptors in the polymorphonuclear leukocyte accumulation induced by IL-1 beta in vivo in the mouse. J Immunol (1996) 156(1):269-74.

8. Campos MM, Souza GE, Calixto JB. In vivo B1 kinin-receptor upregulation. Evidence for involvement of protein kinases and nuclear factor kappaB pathways. Br J Pharmacol (1999) 127(8):1851-9. doi:10.1038/sj.bjp.0702715

9. Morand-Contant M, Anand-Srivastava MB, Couture R. Kinin B1 receptor upregulation by angiotensin II and endothelin-1 in rat vascular smooth muscle cells: receptors and mechanisms. Am J Physiol Heart Circ Physiol (2010) 299(5):H1625-32. doi:10.1152/ajpheart.00735.2009 
10. Sala-Cunill A, Bjorkqvist J, Senter R, Guilarte M, Cardona V, Labrador M, et al. Plasma contact system activation drives anaphylaxis in severe mast cellmediated allergic reactions. J Allergy Clin Immunol (2015) 135(4):1031-43.e6. doi:10.1016/j.jaci.2014.07.057

11. Oschatz C, Maas C, Lecher B, Jansen T, Björkqvist J, Tradler T, et al. Mast cells increase vascular permeability by heparin-initiated bradykinin formation in vivo. Immunity (2011) 34(2):258-68. doi:10.1016/j.immuni. 2011.02.008

12. Moreno-Sanchez D, Hernandez-Ruiz L, Ruiz FA, Docampo R. Polyphosphate is a novel pro-inflammatory regulator of mast cells and is located in acidocalcisomes. J Biol Chem (2012) 287(34):28435-44. doi:10.1074/jbc. M112.385823

13. Scharfstein J, Schmitz V, Morandi V, Capella MM, Lima AP, Morrot A, et al. Host cell invasion by Trypanosoma cruzi is potentiated by activation of bradykinin B(2) receptors. J Exp Med (2000) 192(9):1289-300. doi:10.1084/ jem.192.9.1289

14. Monteiro AC, Scovino A, Raposo S, Gaze VM, Cruz C, Svensjo E, et al. Kinin danger signals proteolytically released by gingipain induce Fimbriae-specific IFN-gamma- and IL-17-producing T cells in mice infected intramucosally with Porphyromonas gingivalis. J Immunol (2009) 183(6):3700-11. doi:10.4049/ jimmunol.0900895

15. Herwald H, Potempa J. Kinins in bacterial infections. In: Bader M, editor. Kinins. Berlin: Verlag Walter de Gruyter GmbH \& Co (2011). p. 307-20.

16. Moncayo A, Silveira AC. Current epidemiological trends for Chagas disease in Latin America and future challenges in epidemiology, surveillance and health policy. Mem Inst Oswaldo Cruz (2009) 104(Suppl 1):17-30. doi:10.1590/S007402762009000900005

17. Morillo CA, Marin-Neto JA, Avezum A, Sosa-Estani S, Rassi A Jr, Rosas F, et al. Randomized trial of benznidazole for chronic Chagas' cardiomyopathy. N Engl J Med (2015) 373(14):1295-306. doi:10.1056/NEJMoa1507574

18. Coura JR, Dias JC. Epidemiology, control and surveillance of Chagas disease: 100 years after its discovery. Mem Inst Oswaldo Cruz (2009) 104(Suppl 1): 31-40. doi:10.1590/S0074-02762009000900006

19. Bastos CJ, Aras R, Mota G, Reis F, Dias JP, de Jesus RS, et al. Clinical outcomes of thirteen patients with acute chagas disease acquired through oral transmission from two urban outbreaks in northeastern Brazil. PLoS Negl Trop Dis (2010) 4(6):e711. doi:10.1371/journal.pntd.0000711

20. Caradonna KL, Engel JC, Jacobi D, Lee CH, Burleigh BA. Host metabolism regulates intracellular growth of Trypanosoma cruzi. Cell Host Microbe (2013) 13(1):108-17. doi:10.1016/j.chom.2012.11.011

21. Marin-Neto JA, Cunha-Neto E, Maciel BC, Simões MV. Pathogenesis of chronic Chagas heart disease. Circulation (2007) 115(9):1109-23. doi:10.1161/ CIRCULATIONAHA.106.624296

22. Dutra WO, Menezes CA, Magalhaes LM, Gollob KJ. Immunoregulatory networks in human Chagas disease. Parasite Immunol (2014) 36(8):377-87. doi:10.1111/pim.12107

23. Silverio JC, Pereira IR, Cipitelli MaC, Vinagre NF, Rodrigues MM, Gazzinelli RT, et al. CD8+ T-cells expressing interferon gamma or perforin play antagonistic roles in heart injury in experimental Trypanosoma cruzi-elicited cardiomyopathy. PLoS Pathog (2012) 8(4):e1002645. doi:10.1371/journal. ppat. 1002645

24. Pinazo MJ, Posada Ede J, Izquierdo L, Tassies D, Marques AF, de Lazzari E, et al. Altered hypercoagulability factors in patients with chronic Chagas disease: potential biomarkers of therapeutic response. PLoS Negl Trop Dis (2016) 10:e0004269. doi:10.1371/journal.pntd.0004269

25. Higuchi ML, Fukasawa S, De Brito T, Parzianello LC, Bellotti G, Ramires JA. Different microcirculatory and interstitial matrix patterns in idiopathic dilated cardiomyopathy and Chagas' disease: a three dimensional confocal microscopy study. Heart (1999) 82(3):279-85. doi:10.1136/hrt.82.3.279

26. Tanowitz HB, Huang H, Jelicks LA, Chandra M, Loredo ML, Weiss LM, et al. Role of endothelin 1 in the pathogenesis of chronic chagasic heart disease. Infect Immun (2005) 73(4):2496-503. doi:10.1128/ iai.73.4.2496-2503.2005

27. Scharfstein J, Andrade D, Svensjo E, Oliveira AC, Nascimento CR. The kallikrein-kinin system in experimental Chagas disease: a paradigm to investigate the impact of inflammatory edema on GPCR-mediated pathways of host cell invasion by Trypanosoma cruzi. Front Immunol (2013) 3:396. doi:10.3389/fimmu.2012.00396
28. Aliberti J, Viola JP, Vieira-de-Abreu A, Bozza PT, Sher A, Scharfstein J. Cutting edge: bradykinin induces IL-12 production by dendritic cells: a danger signal that drives Th1 polarization. J Immunol (2003) 170(11):5349-53. doi:10.4049/ jimmunol.170.11.5349

29. Monteiro AC, Schmitz V, Svensjo E, Gazzinelli RT, Almeida IC, Todorov A, et al. Cooperative activation of TLR2 and bradykinin B2 receptor is required for induction of type 1 immunity in a mouse model of subcutaneous infection by Trypanosoma cruzi. J Immunol (2006) 177(9):6325-35. doi:10.4049/ jimmunol.177.9.6325

30. Monteiro AC, Schmitz V, Morrot A, de Arruda LB, Nagajyothi F, Granato A, et al. Bradykinin B2 receptors of dendritic cells, acting as sensors of kinins proteolytically released by Trypanosoma cruzi, are critical for the development of protective type-1 responses. PLoS Pathog (2007) 3(11):e185. doi:10.1371/ journal.ppat.0030185

31. Schmitz V, Almeida LN, Svensjö E, Monteiro AC, Köhl J, Scharfstein J. C5a and bradykinin receptor cross-talk regulates innate and adaptive immunity in Trypanosoma cruzi infection. J Immunol (2014) 193(7):3613-23. doi:10.4049/ jimmunol.1302417

32. Todorov AG, Andrade D, Pesquero JB, Araujo Rde C, Bader M, Stewart J, et al. Trypanosoma cruzi induces edematogenic responses in mice and invades cardiomyocytes and endothelial cells in vitro by activating distinct kinin receptor (B1/B2) subtypes. FASEB J (2003) 17(1):73-5. doi:10.1096/ fj.02-0477fje

33. Andrade D, Serra R, Svensjo E, Lima AP, Ramos ES Jr, Fortes FS, et al. Trypanosoma cruzi invades host cells through the activation of endothelin and bradykinin receptors: a converging pathway leading to chagasic vasculopathy. Br J Pharmacol (2012) 165(5):1333-47. doi:10.1111/j.1476-5381.2011. 01609.x

34. Kilkenny C, Browne WJ, Cuthill IC, Emerson M, Altman DG. Improving bioscience research reporting: the ARRIVE guidelines for reporting animal research. J Pharmacol Pharmacother (2010) 1(2):94-9. doi:10.4103/0976500x.72351

35. McGrath JC, Lilley E. Implementing guidelines on reporting research using animals (ARRIVE etc.): new requirements for publication in BJP. Br J Pharmacol (2015) 172(13):3189-93. doi:10.1111/bph.12955

36. Xu Y, Cai TQ, Castriota G, Zhou Y, Hoos L, Jochnowitz N, et al. Factor XIIa inhibition by Infestin-4: in vitro mode of action and in vivo antithrombotic benefit. Thromb Haemost (2014) 111(4):694-704. doi:10.1160/TH13-080668

37. Meirelles MN, de Araujo-Jorge TC, Miranda CF, de Souza W, Barbosa HS Interaction of Trypanosoma cruzi with heart muscle cells: ultrastructural and cytochemical analysis of endocytic vacuole formation and effect upon myogenesis in vitro. Eur J Cell Biol (1986) 41(2):198-206.

38. Schmitz V, Svensjo E, Serra RR, Teixeira MM, Scharfstein J. Proteolytic generation of kinins in tissues infected by Trypanosoma cruzi depends on CXC chemokine secretion by macrophages activated via Toll-like 2 receptors. J Leukoc Biol (2009) 85(6):1005-14. doi:10.1189/jlb.1108693

39. Svensjö E, Saraiva EM, Amendola RS, Barja-Fidalgo C, Bozza MT, Lerner EA, et al. Maxadilan, the Lutzomyia longipalpis vasodilator, drives plasma leakage via PAC1-CXCR1/2-pathway. Microvasc Res (2012) 83(2):185-93. doi:10.1016/j.mvr.2011.10.003

40. Svensjo E, Saraiva EM, Bozza MT, Oliveira SM, Lerner EA, Scharfstein J. Salivary gland homogenates of Lutzomyia longipalpis and its vasodilatory peptide maxadilan cause plasma leakage via PAC1 receptor activation. J Vasc Res (2009) 46(5):435-46. doi:10.1159/000197866

41. Fukumizu A, Tsuda Y, Wanaka K, Tada M, Okamoto S, Hijikata-Okunomiya A, et al. Amino acids and peptides. LIII. Synthesis and biological activities of some pseudo-peptide analogs of PKSI-527, a plasma kallikrein selective inhibitor: the importance of the peptide backbone. Chem Pharm Bull (Tokyo) (1999) 47(8):1141-4. doi:10.1248/cpb.47.1141

42. Alvarenga $\mathrm{PH}, \mathrm{Xu} \mathrm{X}$, Oliveira $\mathrm{F}$, Chagas AC, Nascimento $\mathrm{CR}$, Francischetti IM, et al. Novel family of insect salivary inhibitors blocks contact pathway activation by binding to polyphosphate, heparin, and dextran sulfate. Arterioscler Thromb Vasc Biol (2013) 33(12):2759-70. doi:10.1161/ ATVBAHA.113.302482

43. Fogaça SE, Melo RL, Pimenta DC, Hosoi K, Juliano L, Juliano MA. Differences in substrate and inhibitor sequence specificity of human, mouse and rat tissue kallikreins. Biochem J (2004) 380(Pt 3):775-81. doi:10.1042/ BJ20031047 
44. Cummings KL, Tarleton RL. Rapid quantitation of Trypanosoma cruzi in host tissue by real-time PCR. Mol Biochem Parasitol (2003) 129(1):53-9. doi:10.1016/S0166-6851(03)00093-8

45. Fernandes MC, Andrews NW. Host cell invasion by Trypanosoma cruzi: a unique strategy that promotes persistence. FEMS Microbiol Rev (2012) 36(3):734-47. doi:10.1111/j.1574-6976.2012.00333.x

46. De Winne K, Buscher P, Luquetti AQ, Tavares SB, Oliveira RA, Solari A, et al. The Trypanosoma cruzi satellite DNA OligoC-TesT and Trypanosoma cruzi kinetoplast DNA OligoC-TesT for diagnosis of Chagas disease: a multi-cohort comparative evaluation study. PLoS Negl Trop Dis (2014) 8(1):e2633. doi:10.1371/journal.pntd.0002633

47. Almeida IC, Camargo MM, Procópio DO, Silva LS, Mehlert A, Travassos LR, et al. Highly purified glycosylphosphatidylinositols from Trypanosoma cruzi are potent proinflammatory agents. EMBO J (2000) 19(7):1476-85. doi:10.1093/ emboj/19.7.1476

48. Campos MA, Almeida IC, Takeuchi O, Akira S, Valente EP, Procópio DO, et al. Activation of toll-like receptor- 2 by glycosylphosphatidylinositol anchors from a protozoan parasite. J Immunol (2001) 167(1):416-23. doi:10.4049/ jimmunol.167.1.416

49. Meuser-Batista M, Correa JR, Carvalho VF, de Carvalho Britto CF, Moreira OC, Batista MM, et al. Mast cell function and death in Trypanosoma cruzi infection. Am J Pathol (2011) 179(4):1894-904. doi:10.1016/j.ajpath. 2011.06.014

50. Martins PR, Nascimento RD, Lopes JG, Santos MM, de Oliveira CA, de Oliveira EC, et al. Mast cells in the colon of Trypanosoma cruzi-infected patients: are they involved in the recruitment, survival and/or activation of eosinophils? Parasitol Res (2015) 114(5):1847-56. doi:10.1007/s00436-015-4371-9

51. Raud J, Lindbom L, Dahlèn SE, Hedqvist P. Periarteriolar localization of mast cells promotes oriented interstitial migration of leukocytes in the hamster cheek pouch. Am J Pathol (1989) 134(1):161-9.

52. Bilate AM, Salemi VM, Ramires FJ, de Brito T, Silva AM, Umezawa ES, et al. The Syrian hamster as a model for the dilated cardiomyopathy of Chagas' disease: a quantitative echocardiographical and histopathological analysis. Microbes Infect (2003) 5(12):1116-24. doi:10.1016/j. micinf.2003.07.001

53. Siebeck M, Cheronis JC, Fink E, Kohl J, Spies B, Spannagl M, et al. Dextran sulfate activates contact system and mediates arterial hypotension via B2 kinin receptors. J Appl Physiol (1994) 77(6):2675-80.

54. Tibayrenc M, Ayala FJ. The population genetics of Trypanosoma cruzi revisited in the light of the predominant clonal evolution model. Acta Trop (2015) 151:156-65. doi:10.1016/j.actatropica.2015.05.006

55. Soares RP, Torrecilhas AC, Assis RR, Rocha MN, Moura e Castro FA, Freitas GF, et al. Intraspecies variation in Trypanosoma cruzi GPI-mucins: biological activities and differential expression of $\alpha$-galactosyl residues. Am J Trop Med Hyg (2012) 87(1):87-96. doi:10.4269/ajtmh.2012.12-0015
56. Paiva CN, Feijó DF, Dutra FF, Carneiro VC, Freitas GB, Alves LS, et al. Oxidative stress fuels Trypanosoma cruzi infection in mice. JClin Invest (2012) 122(7):2531-42. doi:10.1172/JCI58525

57. Finsterbusch M, Voisin MB, Beyrau M, Williams TJ, Nourshargh S. Neutrophils recruited by chemoattractants in vivo induce microvascular plasma protein leakage through secretion of TNF. J Exp Med (2014) 211(7):1307-14 doi:10.1084/jem.20132413

58. Bartholomeu DC, Ropert C, Melo MB, Parroche P, Junqueira CF, Teixeira SM, et al. Recruitment and endo-lysosomal activation of TLRS in dendritic cells infected with Trypanosoma cruzi. JImmunol (2008) 181(2):1333-44. doi:10.4049/jimmunol.181.2.1333

59. Caetano BC, Carmo BB, Melo MB, Cerny A, dos Santos SL, Bartholomeu DC, et al. Requirement of UNC93B1 reveals a critical role for TLR7 in host resistance to primary infection with Trypanosoma cruzi. J Immunol (2011) 187(4):1903-11. doi:10.4049/jimmunol.1003911

60. Silva GK, Costa RS, Silveira TN, Caetano BC, Horta CV, Gutierrez FR, et al. Apoptosis-associated speck-like protein containing a caspase recruitment domain inflammasomes mediate IL-1beta response and host resistance to Trypanosoma cruzi infection. J Immunol (2013) 191(6):3373-83. doi:10.4049/ jimmunol.1203293

61. Oka T, Hikoso S, Yamaguchi O, Taneike M, Takeda T, Tamai T, et al. Mitochondrial DNA that escapes from autophagy causes inflammation and heart failure. Nature (2012) 485(7397):251-5. doi:10.1038/ nature 10992

62. Murray DB, Gardner JD, Brower GL, Janicki JS. Endothelin-1 mediates cardiac mast cell degranulation, matrix metalloproteinase activation, and myocardial remodeling in rats. Am J Physiol Heart Circ Physiol (2004) 287(5):H2295-9. doi:10.1152/ajpheart.00048.2004

63. Gattoni CM, Aleixo IF, de Araujo MF, Teixeira Vde P, Rodrigues DB, Pereira SA. Chagas disease reactivation in HIV-coinfected patients: histopathological aspects. Immunobiology (2015) 220(5):656-62. doi:10.1016/j. imbio.2014.11.013

Conflict of Interest Statement: The authors declare that the research was conducted in the absence of any commercial or financial relationships that could be construed as a potential conflict of interest.

Copyright (C) 2017 Nascimento, Andrade, Carvalho-Pinto, Serra, Vellasco, Brasil, Ramos-Junior, da Mota, Almeida, Andrade, Correia Soeiro, Juliano, Alvarenga, Oliveira, Sicuro, de Carvalho, Svensjö and Scharfstein. This is an open-access article distributed under the terms of the Creative Commons Attribution License (CC BY). The use, distribution or reproduction in other forums is permitted, provided the original author(s) or licensor are credited and that the original publication in this journal is cited, in accordance with accepted academic practice. No use, distribution or reproduction is permitted which does not comply with these terms. 